Provided for non-commercial research and education use. Not for reproduction, distribution or commercial use.

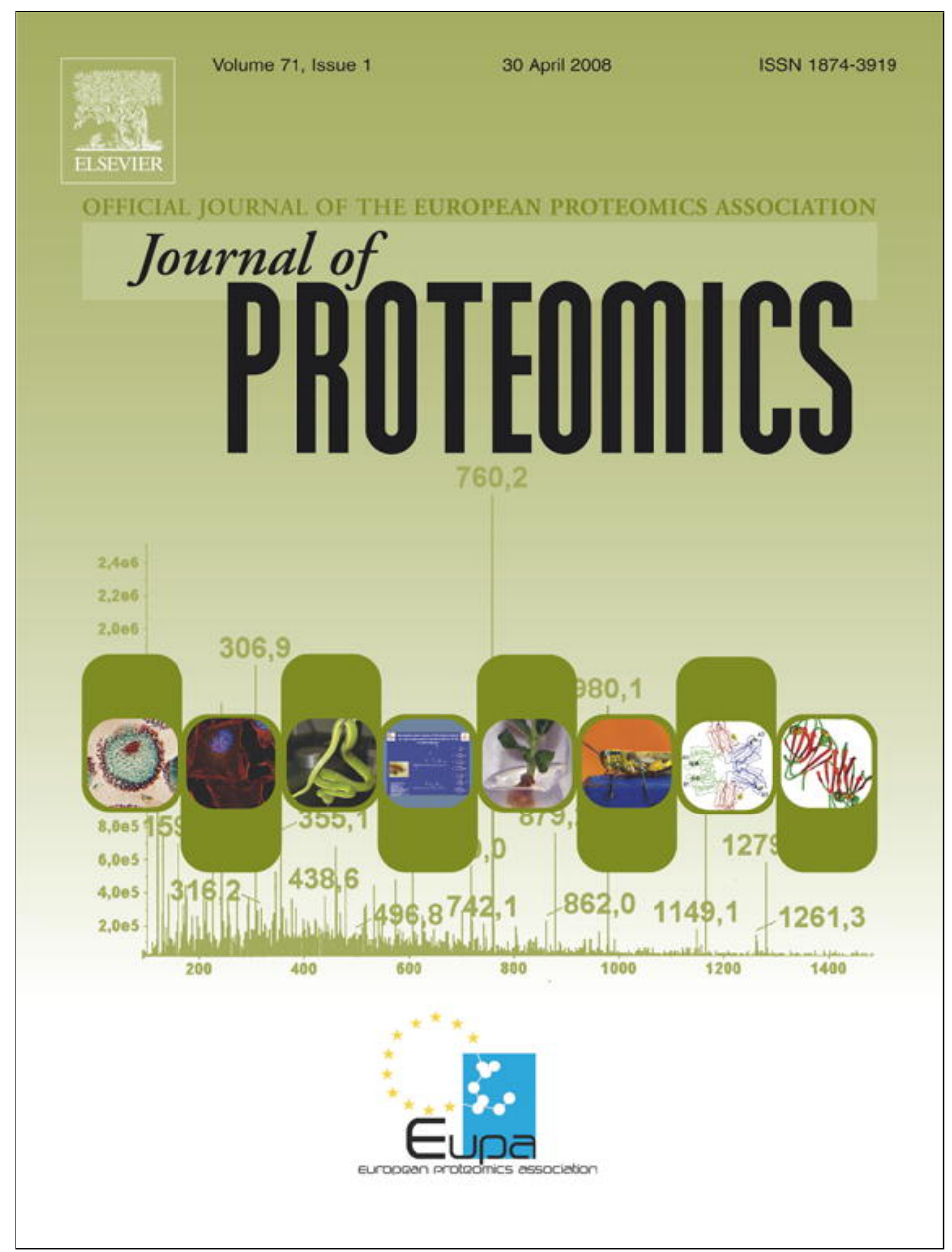

This article appeared in a journal published by Elsevier. The attached copy is furnished to the author for internal non-commercial research and education use, including for instruction at the authors institution and sharing with colleagues.

Other uses, including reproduction and distribution, or selling or licensing copies, or posting to personal, institutional or third party websites are prohibited.

In most cases authors are permitted to post their version of the article (e.g. in Word or Tex form) to their personal website or institutional repository. Authors requiring further information regarding Elsevier's archiving and manuscript policies are encouraged to visit:

http://www.elsevier.com/copyright 


\title{
Snake venomics of the South and Central American Bushmasters. Comparison of the toxin composition of Lachesis muta gathered from proteomic versus transcriptomic analysis
}

\author{
Libia Sanz ${ }^{a}$, José Escolano ${ }^{a}$, Massimo Ferretti $^{b}$, Mirtha J. Biscoglio ${ }^{c}$, \\ Elena Rivera ${ }^{d}$, Ernesto J. Crescenti ${ }^{e}$, Yamileth Angulo ${ }^{f}$, Bruno Lomonte ${ }^{f}$, \\ José María Gutiérrez ${ }^{f}$, Juan J. Calvete ${ }^{a, *}$ \\ ${ }^{a}$ Instituto de Biomedicina de Valencia, C.S.I.C., Valencia, Spain \\ ${ }^{\mathrm{b}}$ Department of Agricultural Biotechnology, University of Padova, Padova, Italy \\ ${ }^{\mathrm{c} D e p a r t a m e n t o ~ d e ~ Q u i m i c a ~ B i o l o g i c a, ~ F a c u l t a d ~ d e ~ F a r m a c i a ~ y ~ B i o q u i m i c a, ~ U n i v e r s i d a d ~ d e ~ B u e n o s ~ A i r e s, ~ B u e n o s ~ A i r e s, ~ A r g e n t i n a ~}$

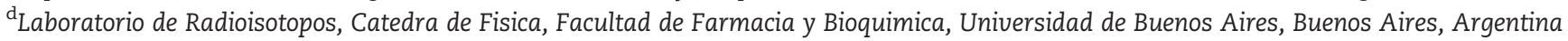 \\ Institute of Immunooncology, Buenos Aires, Argentina \\ ${ }^{\mathrm{f}}$ Instituto Clodomiro Picado, Facultad de Microbiología, Universidad de Costa Rica, San José, Costa Rica
}

\section{A R T I C L E I N F O}

Article history:

Received 25 September 2007

Accepted 19 October 2007

\section{Keywords:}

Snake venomics

Venom proteomics

Snake toxins

Lachesis muta

Lachesis stenophrys

Bushmaster

Pit viper

Mass spectrometry

\begin{abstract}
A B S T R A C T
We report the proteomic characterization of the venoms of two closely related pit vipers of the genus Lachesis, L. muta (South American Bushmaster) and L. stenophrys (Central American Bushmaster), and compare the toxin repertoire of the former revealed through a proteomic versus a transcriptomic approach. The protein composition of the venoms of Lachesis muta and L. stenophrys were analyzed by RP-HPLC, N-terminal sequencing, MALDITOF peptide mass fingerprinting and CID-MS/MS. Around 30-40 proteins of molecular masses in the range of $13-110 \mathrm{kDa}$ and belonging, respectively, to only 8 and 7 toxin families were identified in L. muta and L. stenophrys venoms. In addition, both venoms contained a large number of bradykinin-potentiating peptides (BPP) and a C-type natriuretic peptide (C-NP). BPPs and C-NP comprised around 15\% of the total venom proteins. In both species, the most abundant proteins were $\mathrm{Zn}^{2+}$-metalloproteinases (32-38\%) and serine proteinases (25-31\%), followed by PLA 2 S (9-12\%), galactose-specific C-type lectin (4-8\%), L-amino acid oxidase (LAO, 3-5\%), CRISP (1.8\%; found in L. muta but not in L. stenophrys), and NGF $(0.6 \%)$. On the other hand, only six L. muta venom-secreted proteins matched any of the previously reported 11 partial or full-length venom gland transcripts, and venom proteome and transcriptome depart in their relative abundances of different toxin families. As expected from their close phylogenetic relationship, the venoms of L. muta and L. stenophrys share (or contain highly similar) proteins, in particular BPPs, serine proteinases, a galactose-specific C-type lectin, and LAO. However, they dramatically depart in their respective $\mathrm{PLA}_{2}$ complement. Intraspecific quantitative and qualitative differences in the expression of $\mathrm{PLA}_{2}$ molecules were found when the venoms of five L. muta specimens ( 3 from Bolivia and 2 from Peru) and the venom of the same species purchased from Sigma were compared. These observations indicate that these class of toxins represents a rapidly-evolving
\end{abstract}

\footnotetext{
* Corresponding author. Instituto de Biomedicina de Valencia, C.S.I.C., Jaime Roig 11, 46010 Valencia, Spain. Tel.: +34 963391778 ; fax: +34 96 3690800.

E-mail address: jcalvete@ibv.csic.es (J.J. Calvete).
}

1874-3919/\$ - see front matter @ 2007 Elsevier B.V. All rights reserved. doi:10.1016/j.jprot.2007.10.004 
gene family, and suggests that functional differences due to structural changes in PLA $_{2} \mathrm{~S}$ molecules among these snakes may have been a hallmark during speciation and adaptation of diverging snake populations to new ecological niches, or competition for resources in existing ones. Our data may contribute to a deeper understanding of the biology and ecology of these snakes, and may also serve as a starting point for studying structure-function correlations of individual toxins.

(c) 2007 Elsevier B.V. All rights reserved.

1.

Venom toxins likely evolved from proteins with a normal physiological function and appear to have been recruited into the venom proteome before the diversification of the advanced snakes, at the base of the Colubroidea radiation [1-4]. Given the central role that diet has played in the adaptive radiation of snakes [5], venoms represent the critical innovation that allowed advanced snakes to transition from a mechanical (constriction) to a chemical (venom) means of subduing and digesting prey larger than themselves, and as such, venom proteins have multiple functions including immobilizing, paralyzing, killing and digesting prey. Venoms produced by snakes of the family Viperidae (vipers and pit vipers) contain proteins that interfere with the coagulation cascade, the normal haemostatic system and tissue repair, and human envenomations are often characterized by clotting disorders, hypofibrinogenemia and local tissue necrosis [6,7]. In spite of the fact that viperid venoms may contain well over 100 protein components [8], venom proteins belong to only a few major protein families, including enzymes (serine proteinases, $\mathrm{Zn}^{2+}$-metalloproteinases, L-amino acid oxidase, group II $\mathrm{PLA}_{2}$ ) and proteins without enzymatic activity (disintegrins, Ctype lectins, natriuretic peptides, myotoxins, CRISP toxins, nerve and vascular endothelium growth factors, cystatin and Kunitz-type proteinase inhibitors). However, snake venoms depart from each other in the composition and the relative abundance of toxins [1,2,8-14].

In addition to understanding how venoms evolve, characterization of the protein/peptide content of snake venoms also has a number of potential benefits for basic research, clinical diagnosis, development of new research tools and drugs of potential clinical use, and for antivenom production strategies [15]. Within- and between-species heterogeneity of venoms may also account for differences in the clinical symptoms observed in accidental envenomations. In order to explore the putative venom components, several laboratories have carried out transcriptomic analyses of the venom glands of viperid (Bitis gabonica [16], Bothrops insularis [17], Bothrops jararacussu [18], Bothrops jararaca [19], Agkistrodon acutus [20,21], Echis ocellatus [22], and Lachesis muta [23]), elapid (Oxyuramus scutellatus [24]), and colubrid (Philodryas olfersii [25]) snake species. Transcriptomic investigations provide catalogues of partial and full-length transcripts that are synthesized by the venom gland. Here, we report a proteomic analysis of L. muta venom, which complements the study of snake venom gene transcriptional activity (transcriptome) in the same species [23] by showing the relative abundance of the various protein families that are actually secreted into the venoms.

Lachesis is a genus of venomous pit vipers widely distributed in remote, lowland tropical forested areas in Central and South America, and the only neo-tropical pit viper that lays eggs. Three species are currently recognized in this genus, L. muta (South American bushmaster), L. stenophrys (Central American bushmaster), and L. melanocephala (Black-headed bushmaster) (http://www.reptile-database.org) . The bushmasters are the largest of all pit vipers and the longest venomous snakes in the western hemisphere. Adults grow to an average of 2 to $2.5 \mathrm{~m}$, although $3 \mathrm{~m}$ is not too unusual.

Lachesis melanocephala is endemic of the pacific versant of Costa Rica, where it is confined to the southwestern Osa Peninsula [26]. L. muta is found in South America in the equatorial forests east of the Andes, ranging from Colombia, eastern Ecuador, Peru, northern Bolivia, eastern and southern Venezuela, to Guyana, Surinam, French Guiana and much of northern Brazil. Lachesis stenophrys, is found in the Atlantic lowlands of southern Nicaragua, Costa Rica and the Atlantic and Pacific lowlands of central and eastern Panama. In South America it occurs in the Pacific lowlands of Colombia and northwestern Ecuador, the Caribbean coast of northwestern Colombia and inland along the Magdalena and Cauca river valleys.

Human envenoming by Lachesis (muta or stenophrys) are infrequent but rather severe and characterized by conspicuous local tissue damage (edema, hemorrhage and necrosis), nausea, coagulopathies, hypotension, shock and renal disturbances [27]. Brown [28] mentions a venom yield of 200$411 \mathrm{mg}$ from $\mathrm{L}$. muta and gives the following $\mathrm{LD}_{50 \%}$ values for mice: $1.5 \mathrm{mg} / \mathrm{kg}$ (i.v.), $1.6-6.2 \mathrm{mg} / \mathrm{kg}$ (i.p.), $6.0 \mathrm{mg} / \mathrm{kg}$ (s.c.). Paradoxically, although bites can be deadly, snake venoms also contain components of theraupeutic value. The venom of L. muta has attracted medical interest because its reported protective effect in rats subjected to high cytostatic doses, when administered at low $(4 \mathrm{ng} / \mathrm{ml})$ concentration in combination with $\mathrm{Mg}$, Se, $\mathrm{Zn} \mathrm{(4 \mu g/ml} \mathrm{each)} \mathrm{[29].} \mathrm{It} \mathrm{has} \mathrm{been} \mathrm{also}$ reported that administration of this formulation to nude mice that had developed tumors by inoculation of PANC-1 cells, inhibited tumor growth and angiogenesis, induced apoptosis, and modulated the activity of antioxidant enzymes [30]. Ongoing research from our laboratories, which will be published elsewhere, indicates that daily subcutaneous administration of L. muta venom $(0.5 \mathrm{ml}, 4 \mathrm{ng} / \mathrm{ml})$ significantly $(p<0.05)$ increased the survival of $\mathrm{N}$-nitroso- $\mathrm{N}$-methylureainduced tumor-bearing rats (103 days) compared to non-Lmtreated animals (66 days). Furthermore, the venom provoked 
Table 1 - Assignment of the reverse-phase fractions of Lachesis muta venom (Santa Cruz de la Sierra, Bolivia), isolated as in , to protein families by $\mathrm{N}$-terminal Edman sequencing, mass spectrometry, and collision-induced fragmentation by nESI-MS/MS of selected peptide ions from in-gel digested protein bands (separated by SDS-PAGE as in

\begin{tabular}{|c|c|c|c|c|c|c|}
\hline \multirow{2}{*}{$\begin{array}{l}\begin{array}{l}\text { HPLC } \\
\text { fraction }\end{array} \\
\text { Lm- }\end{array}$} & \multirow[t]{2}{*}{$\begin{array}{l}\mathrm{N} \text {-terminal } \\
\text { sequencing }\end{array}$} & \multicolumn{3}{|c|}{$\begin{array}{c}\text { Isotope-averaged Peptide } \\
\text { molecular ion }\end{array}$} & \multirow[t]{2}{*}{$\begin{array}{l}\text { MS/MS-derived } \\
\text { sequence }\end{array}$} & \multirow[t]{2}{*}{ Protein family } \\
\hline & & & $\mathrm{m} / \mathrm{z}$ & $\bar{z}$ & & \\
\hline \multirow[t]{3}{*}{1} & N.D. & 384.0 & & 2 & Ac-TPPAGPD $(+41)$ & [Q27J49] \\
\hline & & 465.6 & & 2 & TPPAGPDVGP(+91) & BPP-C-NP precursor \\
\hline & & 581.8 & & 2 & DHHAVGGGGGGGGA(+91) & \\
\hline 2 & N.D. & 480.6 & & 2 & ZKKWPPGH & [Q27J49] \\
\hline \multirow[t]{5}{*}{3} & N.D. & 532.1 & & 2 & TPPAGPDVGPR & [Q27J49] \\
\hline & & 482.0 & & 2 & PPAGPDVGPR & \\
\hline & & 768.5 & & 1 & AGPDVGPR & \\
\hline & & 697.4 & & 1 & GPDVGPR & \\
\hline & & 543.5 & & 1 & DVGPR & \\
\hline 4,5 & n.p. & & & & & \\
\hline \multirow[t]{2}{*}{6} & N.D. & 702.6 & & 2 & ZKKWPPGHHIPP & [Q27J49] \\
\hline & & 764.1 & & 1 & ZKKWPP & \\
\hline \multirow[t]{3}{*}{7} & N.D. & 597.2 & & 2 & ZKKWPPGHHI & [Q27J49] \\
\hline & & 549.0 & & 2 & ZKKWPPGHH & \\
\hline & & 582.9 & & 2 & (308.4)KWPPGHH & \\
\hline 8 & N.D. & 725.5 & & 3 & HHIPPVVVQEWPPGHHIPP & [Q27J49] \\
\hline 9 & N.D. & 639.3 & & 2 & ZEWPPGHHIPP & [Q27J49] \\
\hline \multirow[t]{4}{*}{10} & N.D. & 623.1 & & 2 & ZKWDPPPISPP & [Q27J49] \\
\hline & & 544.1 & & 2 & WDPPPISPP & \\
\hline & & 945.5 & & 1 & ZKWDPPPI & \\
\hline & & 1032.5 & & 1 & ZKWDPPPIS & \\
\hline \multirow[t]{7}{*}{11} & N.D. & 868.7 & & 3 & $\begin{array}{l}\text { ZKWDPPPISPPLLKPHES } \\
\text { PAGGTTA }\end{array}$ & [Q27J49] \\
\hline & & 845.1 & & 3 & $\begin{array}{l}\text { ZKWDPPPISPPLLKPHE } \\
\text { SPAGGTT }\end{array}$ & \\
\hline & & 758.7 & & 3 & $\begin{array}{l}\text { SPAGGTT } \\
\text { ZKWDPPPISPPLLKPHESPAG }\end{array}$ & \\
\hline & & 653.0 & & 3 & ZKWDPPPISPPLLKPHE & \\
\hline & & 611.5 & & 3 & ZKWDPPPISPPLLKPH & \\
\hline & & 688.7 & & 3 & PPPISPPLLKPHESPAGGTTA & \\
\hline & & 578.6 & & 3 & PPPISPPLLKPHESPAG & \\
\hline \multirow[t]{2}{*}{12} & N.D. & 715.8 & & 3 & ZKWDPPPISPPLLKPHESP & [Q27J49] \\
\hline & & 679.3 & & 2 & ZKWDPPPISPPL & \\
\hline \multirow[t]{2}{*}{13} & GDGCFGLKLDRIGSMSGLGC & 1983.4 & & & & C-NP [Q27J49] \\
\hline & GCFGLKLDRIGSMSGLGC & 1811.6 & & & & \\
\hline 14 & Blocked & 12041,12154 & & & & unknown \\
\hline \multirow[t]{3}{*}{15} & Blocked & $16 \mathrm{kDa}=\boldsymbol{\nabla}$ & 556.2 & 2 & NPNPVPTGCR & Nerve growth factor \\
\hline & & & 632.1 & 2 & IDAACVCISR & \\
\hline & & & 682.1 & 2 & ALTMEGNQASWR & \\
\hline \multirow[t]{2}{*}{16} & HLLQFGDLINKIARRNGIS- & 13932.6 & 649.6 & 2 & HLLQFGDLINK & $\mathrm{PLA}_{2}$ \\
\hline & -YYGFYGCYCGL & & 605.3 & 3 & EICECDRDAAICFR & \\
\hline \multirow[t]{7}{*}{17} & HLLQFGDLINKIARRNGIS- & 13916.3 & 649.1 & 2 & HLLQFGDLINK & $\mathrm{PLA}_{2}$ \\
\hline & -YYGFYG & & 605.3 & 3 & EICECDRDAAICFR & \\
\hline & & & 490.7 & 2 & EICECDR & \\
\hline & & & 548.7 & 2 & DNLDTYDNK & \\
\hline & & & 752.7 & 2 & CCFVHDCCYGK & \\
\hline & & & 512.7 & 2 & YWFFHPK & \\
\hline & & & 507.9 & 2 & GRPQDATDR & \\
\hline 18 & m: HLLQFEQLIRKIAGRSGFRYYGFY- & & & & & \\
\hline & -GCYCGLGGQGRPQDA & 14008.6 & & & & $\mathrm{PLA}_{2}$ \\
\hline & M: SVDFDSESPRKPEIQNKIVDLHNSL & 24683.9 & & & & CRISP \\
\hline 19 & VFGGDECNINEHRSLVVLFNSS & $30 \mathrm{kDa}$ & & & & 2-chain Ser-proteinase \\
\hline & TSTTLCAGILEGGKDSCHGDSG & & & & & [Q27J47] \\
\hline & SVDFDSESPRKPEIQ & 24683.8 & & & & CRISP \\
\hline 20 & IIGGDECNINEHRSL & $28 \mathrm{kDa}$ - & 647.5 & 2 & XNXXDYEVCR & Ser-proteinase \\
\hline & & & 763.8 & 2 & IIGGDECNINEHR & \\
\hline & VFGGDECNINEHRSL & $26 \mathrm{kDa}$ & 608.1 & 2 & KVPNKDEETR & Ser-proteinase [Q27J47] \\
\hline & & & 714.9 & 2 & SLPSSPPSVGSVCR & \\
\hline & & & 773.4 & 2 & VFGGDECNINEHR & \\
\hline & SVDFDSESPRKPEIQ & $24 \mathrm{kDa}$ & & & & CRISP \\
\hline
\end{tabular}


Table 1 (continued)

\begin{tabular}{|c|c|c|c|c|c|c|}
\hline \multirow{2}{*}{$\begin{array}{l}\text { HPLC } \\
\text { fraction } \\
\text { Lm- }\end{array}$} & \multirow[t]{2}{*}{$\begin{array}{l}\mathrm{N} \text {-terminal } \\
\text { sequencing }\end{array}$} & \multicolumn{3}{|c|}{$\begin{array}{c}\text { Isotope-averaged Peptide } \\
\text { molecular ion }\end{array}$} & \multirow[t]{2}{*}{$\begin{array}{l}\text { MS/MS-derived } \\
\text { sequence }\end{array}$} & \multirow[t]{2}{*}{ Protein family } \\
\hline & & & $m / z$ & z & & \\
\hline 21 & $\begin{array}{l}\text { VFGGDECNINEHRSL } \\
\text { VVLFNSS }\end{array}$ & $27 \mathrm{kDa}$ " & & & & Ser-proteinase [Q27J47] \\
\hline \multirow[t]{2}{*}{22} & $\begin{array}{l}\text { M: NNCPQDWLPMNG } \\
\text { LCYKIFD }\end{array}$ & $\begin{array}{l}28 \mathrm{kDa} \because / \\
14 \mathrm{kDa} \nabla\end{array}$ & & & & Gal-lectin [Q9PSM4] \\
\hline & $\begin{array}{l}\text { m: VIGGDECNINEHR } \\
\text { FLVALY }\end{array}$ & $29 \mathrm{kDa} \nabla$ & & & & Ser-proteinase [P33589] \\
\hline \multirow[t]{2}{*}{23} & $\begin{array}{l}\text { M: VIGGDECNINEHRFLVALYDG- } \\
\text {-LSGTFLCG }\end{array}$ & $30 \mathrm{kDa} \boldsymbol{\nabla}$ & & & & $\begin{array}{l}\text { Ser-proteinase [P33589] } \\
\text { Venombin A }\end{array}$ \\
\hline & $\begin{array}{l}\text { m: VFGGDECNINEHRSLVVLFNS- } \\
\text {-SGFLCAGT }\end{array}$ & $30 \mathrm{kDa} \nabla$ & & & & Ser-proteinase [Q27J47] \\
\hline \multirow[t]{6}{*}{$23-29$} & $\begin{array}{l}\text { NNCPQDWLPMNGL } \\
\text { CYKIFD }\end{array}$ & $28 \mathrm{kDa}$ & 639.6 & 2 & LWNDQVCESK & Gal-lectin [Q9PSM4] \\
\hline & & $14 \mathrm{kDa} \nabla$ & 620.9 & 2 & DFSWEWTDR & \\
\hline & & & 644.3 & 2 & SCTDYLTWDK & \\
\hline & & & 665.8 & 2 & AWEDAEmFCR & \\
\hline & & & 786.8 & 2 & EFCVELVSLTGYR & \\
\hline & & & 639.3 & 3 & YGESLEIAEYISDYHK & \\
\hline 24 & $\begin{array}{l}\text { IVGGDECNINEHRFL } \\
\text { VALYDP }\end{array}$ & $30 \mathrm{kDa} \nabla$ & & & & Serine proteinase \\
\hline 25 & $\begin{array}{l}\text { VIGGDECNINEHRF } \\
\text { LVALYD }\end{array}$ & $30 \mathrm{kDa} \nabla$ & & & & Serine proteinase [P33589] \\
\hline \multirow[t]{6}{*}{26,27} & $\begin{array}{l}\text { VIGGDECNINEHRSL } \\
\text { VALYD }\end{array}$ & $38 \mathrm{kDa} \boldsymbol{\nabla}$ & 575.5 & 2 & NVKFDDEQR & Serine proteinase Venombin A \\
\hline & & & 756.9 & 2 & VIGGDECNINEHR & (S35689) \\
\hline & & & 867.3 & 2 & VLCAGVLEGGIDTCNR & \\
\hline & & & 772.8 & 2 & SLPSNPPSEDSVCR & \\
\hline & $\begin{array}{l}\text { VFGGDECNINEHR } \\
\text { SLVVLFN }\end{array}$ & $31 \mathrm{kDa} \boldsymbol{\top}$ & 773.9 & 2 & VFGGDECNINEHR & Serine proteinase (P84036) \\
\hline & & & 711.5 & 2 & AIYPEFGLPATSR & Plasminogen-activator \\
\hline \multirow[t]{2}{*}{28} & VFGGDECNINEHRSLVV & $31 \mathrm{kDa} \nabla$ & 791.4 & 2 & CANINLLDYAVCR & Serine proteinase \\
\hline & & & 744.6 & 2 & (261.2)PSSPPSVGSVCR & \\
\hline \multirow[t]{2}{*}{$28-38$} & & $29 \mathrm{kDa}$ & & & & \\
\hline & & $14 \mathrm{kDa} \nabla$ & 459.8 & 3 & GHCYKPFNEPK & C-type lectin-like \\
\hline \multirow[t]{3}{*}{29} & $\begin{array}{l}\text { ADDRNPLGECFRETD } \\
\text { YEEFLEIAK }\end{array}$ & $58 \mathrm{kDa}=\nabla$ & 583.1 & 2 & KFWEDDGIR & L-amino acid oxidase \\
\hline & & & 641.0 & 2 & SAGQLYEESLGK & \\
\hline & & & 744.1 & 2 & ETDYEEFLEIAK & \\
\hline \multirow[t]{4}{*}{30} & (NFPPYEANIMRV) & $26 \mathrm{kDa}=\boldsymbol{\nabla}$ & 781.3 & 2 & VHEIVNTLNGFYR & PI-metalloproteinase(P22796) \\
\hline & & & 590.1 & 2 & TFGEWRER & Hemorrhagic factor LHFII \\
\hline & & & 641.1 & 2 & NSVGIVQDHSPK & \\
\hline & & & 869.5 & 2 & YIELVVVADHGmFTK & \\
\hline \multirow[t]{4}{*}{31} & Blocked & $26 \mathrm{kDa}=\nabla$ & 781.3 & 2 & VHEIVNTLNGFYR & PI-metalloproteinase (P22796) \\
\hline & & & 590.1 & 2 & TFGEWRER & Hemorrhagic factor LHFII \\
\hline & & & 641.1 & 2 & NSVGIVQDHSPK & \\
\hline & & & 869.5 & 2 & YIELVVVADHGmFTK & \\
\hline \multirow[t]{5}{*}{32,33} & Blocked & $37 \mathrm{kDa}=\boldsymbol{\nabla}$ & 518.8 & 2 & SVGIVQDYR & PIII-Metalloproteinase \\
\hline & & & 672.2 & 3 & LTPGSQCADGECCDQCR & \\
\hline & & & 671.3 & 2 & YIELVLLADHR & \\
\hline & & $26 \mathrm{kDa} \cdot \boldsymbol{\nabla}$ & 781.3 & 2 & VHEIVNTLNGFYR & $\begin{array}{l}\text { PI-metalloproteinase } \\
\text { (P22796) }\end{array}$ \\
\hline & & & 590.1 & 2 & TFGEWRER & Hemorrhagic factor LHFII \\
\hline \multirow[t]{2}{*}{34} & Blocked & $58 \mathrm{kDa}=\boldsymbol{\nabla}$ & 752.6 & 2 & XFCEFNNFPCR & PIII-Metalloproteinase \\
\hline & & & 650.0 & 2 & YVEXVVVADHR & \\
\hline \multirow[t]{5}{*}{35} & Blocked & $27 \mathrm{kDa} \nabla \boldsymbol{\nabla}$ & 577.6 & 2 & ZVVTAEQQR & PI-Metalloproteinase \\
\hline & & & 604.6 & 2 & QGAQCAEGLCCDQCR & \\
\hline & & & 530.3 & 2 & XACEPQDVK & \\
\hline & & & 627.2 & 2 & PQCXXQQXPR & \\
\hline & & & 635.6 & 2 & LYCFPSSPATK & \\
\hline \multirow[t]{2}{*}{36} & Blocked & $110 \mathrm{kDa}$ & 761.9 & 2 & SAAADTXEAFADWR & (PIII-Metalloproteinase) ${ }_{2}$ \\
\hline & & $49 \mathrm{kDa} \nabla$ & 594.9 & 3 & (581.5)VVVADHN(467.0) & \\
\hline
\end{tabular}




\section{Table 1 (continued)}

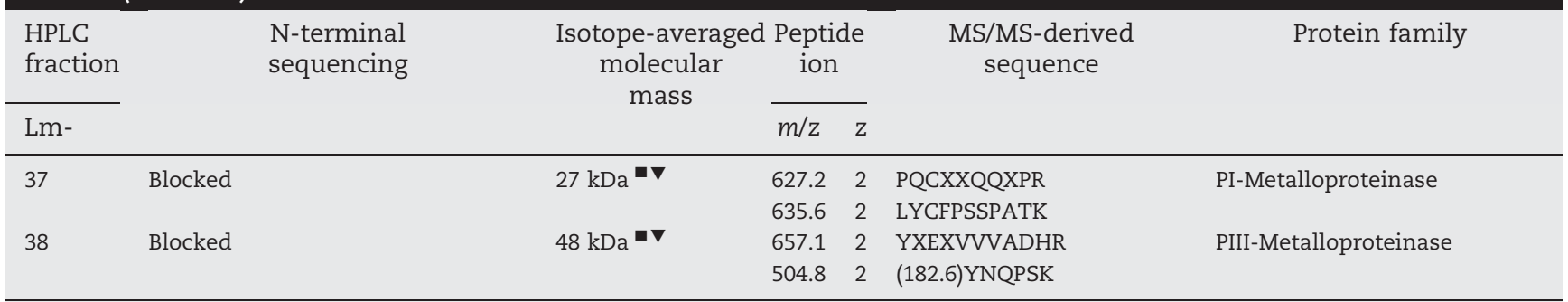

$\mathrm{X}$, Ile or Leu; Z, pyrrolidone carboxylic acid; Ac-, N-acetyl; $m$, methionine sulphoxide. Unless other stated, for MS/MS analyses, cysteine residues were carbamidomethylated. Molecular masses of native proteins were determined by electrospray-ionization $( \pm 0.02 \%)$ or MALDI-TOF $(*)( \pm 0.2 \%)$ mass spectrometry. Apparent molecular mass determined by SDS-PAGE of non-reduced ( $\nabla$ ) and reduced ( $\boldsymbol{\nabla}$ ) samples; n.p., non-peptidic material found. $\mathrm{M}$ and $\mathrm{m}$, denote mayor and minor products co-eluting in the same HPLC fraction. Previously reported proteins are identified by their databank accession codes.

50-70\% cell proliferation inhibition of cultured human neoplasia-derived cell lines MDA-MB-231 and MCF-7 (breast cancer), PANC-1 (pancreatic carcinoma), WM35 and HT168 (melanoma), and U937 (histiocytic lymphoma).

Otero and co-workers [31] have reported quantitative differences in toxic and enzymatic activities along with subtle variations in the electrophoretic patterns of L. muta and L. stenophrys venoms from Brazil, Colombia, and Costa Rica, although experimental envenomation by these venoms induced a qualitatively similar pathophysiological profile. Here, we report the proteomic characterization of the toxin composition of L. muta and L. stenophrys venoms, and compare the toxin repertoire of the former revealed through a proteomic versus a transcriptomic approach. Venom toxin composition provides a comprehensible catalogue of the venom-secreted proteins, which may contribute to a deeper understanding of the biology and ecology of the snake, the biological effects of the venom, and may also serve as a starting point for studying structure-function correlations of individual toxins.

\section{Experimental section}

\subsection{Isolation and relative quantitation of venom proteins}

Venom of L. stenophrys (Central American Bushmaster) was pooled from specimens collected in Costa Rica and kept at the serpentarium of the Instituto Clodomiro Picado, University of Costa Rica in San José. L. muta (South American Bushmaster) venom samples were obtained from 3 wild caught specimens and were kindly provided by SICAE' s.r.l., a snakes farm located in the nature reserve Potrerillos del Guendá (Santa Cruz de la Sierra, Bolivia, P.O. Box 1615) (www.sicae-online. com). Venoms from 2 specimens of L. muta from Peru (Iquitos, Departamento de Loreto or Cenepa, Mamayaque) were also analyzed. A further sample of L. muta venom was purchased from Sigma-Aldrich (Alcobendas, Madrid, Spain; catalog no. V7376). The source of this venom was not provided by the vendor. For reverse-phase HPLC separations, 2-5 mg of crude, lyophillized venom of L. muta were dissolved in $100 \mu$ l of $0.05 \%$ trifluoroacetic acid (TFA) and 5\% acetonitrile, and insoluble material was removed by centrifugation in an Eppendorff centrifuge at $13,000 \times \mathrm{g}$ for $10 \mathrm{~min}$ at room temperature.
Proteins in the soluble material were separated using an ETTAN $^{\mathrm{TM}}$ LC HPLC system (Amersham Biosciences) and a Lichrosphere RP100 $\mathrm{C}_{18}$ column $(250 \times 4 \mathrm{~mm}, 5 \mu \mathrm{m}$ particle size $)$ eluted at $1 \mathrm{ml} / \mathrm{min}$ with a linear gradient of $0.1 \%$ TFA in water (solution A) and acetonitrile (solution B) (5\% B for $10 \mathrm{~min}$, followed by 5-15\% B over $20 \mathrm{~min}, 15-45 \%$ B over $120 \mathrm{~min}$, and $45-70 \%$ B over $20 \mathrm{~min}$ ). Protein detection was at $215 \mathrm{~nm}$ and peaks were collected manually and dried in a Speed-Vac (Savant). Given that the wavelength of absorbance for a peptide bond is $190-230 \mathrm{~nm}$, protein detection at $215 \mathrm{~nm}$ allows to estimate the relative abundances (expressed as percentage of the total venom proteins) of the different protein families from the relation of the sum of the areas of the reverse-phase chromatographic peaks containing proteins from the same family to the total area of venom protein peaks in the reverse-phase chromatogram. In a strict sense, and according to the Lambert-Beer law, the calculated relative amounts correspond to the "\% of total peptide bonds in the sample", which is a good estimate of the \% by weight (gr/100gr) of a particular venom component.

\subsection{Characterization of HPLC-isolated proteins}

Isolated protein fractions were subjected to $\mathrm{N}$-terminal sequence analysis (using a Procise instrument, Applied Biosystems, Foster City, CA, USA) following the manufacturer's instructions. Amino acid sequence similarity searches were performed against a non-redundant protein sequence databank (comprising all non-redundant GenBank CDS translations + RefSeq Proteins + PDB + SwissProt + PIR + PRF) (http:// www.ncbi.nlm.nih.gov/BLAST/blastcgihelp.shtml\#protein_data bases) using the BLAST program [32] implemented in the WUBLAST2 search engine at http://www.bork.embl-heidelberg.de. The molecular masses of the purified proteins were determined by SDS-PAGE (on 12-15\% polyacrylamide gels) and by electrospray ionization (ESI) mass spectrometry using an Applied Biosystems QTrap ${ }^{\mathrm{TM}} 2000$ mass spectrometer [33] operated in Enhanced Multiple Charge mode in the range $\mathrm{m} / \mathrm{z}$ 600-1200.

\subsection{In-gel enzymatic digestion and mass fingerprinting}

Protein bands of interest were excised from a Coomassie Brilliant Blue-stained SDS-PAGE and subjected to automated 
reduction with DTT and alkylation with iodoacetamide, and digestion with sequencing grade bovine pancreas trypsin (Roche) using a ProGest ${ }^{\mathrm{TM}}$ digestor (Genomic Solutions) following the manufacturer's instructions. The tryptic peptide mixtures were dried in a Speed-Vac and redissolved in $5 \mu \mathrm{l}$ of $70 \%$ acetonitrile and $0.1 \%$ TFA. Digests $(0.65 \mu \mathrm{l})$ were spotted onto a MALDI-TOF sample holder, mixed with an equal volume of a saturated solution of $\alpha$-cyano-4-hydroxycinnamic acid (Sigma) in 50\% acetonitrile containing 0.1\% TFA, dried, and analyzed with an Applied Biosystems Voyager-DE Pro MALDITOF mass spectrometer, operated in delayed extraction and reflector modes. A tryptic peptide mixture of Cratylia floribunda seed lectin (SwissProt accession code P81517) prepared and previously characterized in our laboratory was used as mass calibration standard (mass range, 450-3300 Da).

\subsection{CID-MS/MS}

For peptide sequencing, the protein digest mixture was loaded in a nanospray capillary column and subjected to electrospray ionization mass spectrometric analysis using a QTrap 2000 mass spectrometer (Applied Biosystems) [33] equipped with a nanoelectrospray source (Protana, Denmark). Doubly- or triplycharged ions of selected peptides from the MALDI-TOF mass fingerprint spectra were analyzed in Enhanced Resolution MS mode and the monoisotopic ions were fragmented using the Enhanced Product Ion tool with Q trapping. Enhanced Resolution was performed at $250 \mathrm{amu} / \mathrm{s}$ across the entire mass range. Settings for MS/MS experiments were as follows: Q1-unit resolution; Q1-to-Q2 collision energy - 30-40 eV; Q3 entry barrier - 8 V; LIT (linear ion trap) Q3 fill time - $250 \mathrm{~ms}$; and Q3 scan rate $-1000 \mathrm{amu} / \mathrm{s}$. CID spectra were interpreted manually or using a licensed version of the MASCOT program (http:// www.matrixscience.com) against a private database containing 927 viperid protein sequences deposited in the SwissProt/ TrEMBL database (Knowledgebase Release 12 of July 2007; http://us.expasy.org/sprot/). MS/MS mass tolerance was set to $\pm 0.6 \mathrm{Da}$. Carbamidomethyl cysteine and oxidation of methione were fixed and variable modifications, respectively.

\subsection{Variation in venom composition between Lachesis taxa}

We used similarity coefficients to estimate the similarity of venom proteins between taxa. These coefficients are similar to the bandsharing coefficients used to compare individual genetic profiles based on multilocus DNA fingerprints [34]. We defined the Protein Similarity Coefficient (PSC) between two species "a" and "b" in the following way: $\mathrm{PSC}_{\mathrm{ab}}=[2 \times($ no. of proteins shared between a and b)/(total number of distinct proteins in a+total number of distinct proteins in $b)] \times 100$. We judged two proteins (listed in Tables 1 and 2) as being different when they met one or more of these criteria: 1) Had different $\mathrm{N}$-terminal sequences and/or distinct internal peptides sequences (derived from MS/MS data) corresponding to homologous regions; 2) had different peptide mass fingerprints; 3) were of different sizes (judged by MALDI-TOF MS or SDS-PAGE). For these comparisons, two proteins were judged to differ in size if they differed by more than our estimate of the $95 \%$ confidence interval for particular sizing techniques $(0.01 \%$ for ESI-QTrap MS; 0.4\% for MALDI-TOF MS-derived masses, and
+1.4 kDa for SDS-PAGE-determined masses); or 4) eluted in different reverse-phase HPLC peaks. We emphasize that these measures will give only minimum estimates of the similarities between the venom profiles. We suspect that a number of the proteins that we judge to be the same using the above criteria would be found to differ at one or more of these criteria if more complete information were available.

\section{Results and discussion}

\subsection{Characterization of bushmaster venom proteomes}

The crude venoms of L. muta and L. stenophrys were fractionated by reverse-phase HPLC (Figs. 1 and 3), followed by analysis of each chromatographic fraction by SDS-PAGE (Figs. 2 and 4) and N-terminal sequencing. Molecular masses of purified proteins were determined by ESI-MS or MALDI-TOF mass spectrometry (Tables 1 and 2). Fig. 5A displays an example of electrospray-ionization mass spectrum of the $25 \mathrm{kDa}$ protein isolated in fraction 18 (Figs. 1 and 2) and identified as a member of the CRISP family (Table 1). Protein fractions showing single electrophoretic band, molecular mass, and N-terminal sequence were straightforwardly assigned by BLAST analysis (http://www.ncbi.nlm.nih.gov/ BLAST) to a known protein family, indicating that representative members of most snake venom toxin families are present amongst the 927 viperid protein sequences deposited to date in the SwissProt/TrEMBL database. Protein fractions showing heterogeneous or blocked N-termini were analyzed by SDSPAGE and the bands of interest are subjected to automated reduction, carbamidomethylation, and in-gel tryptic digestion in a ProGest digestor (Genomic Solutions). The resulting tryptic peptides are then analyzed by MALDI-TOF mass fingerprinting followed by amino acid sequence determination of selected doubly- and triply-charged peptide ions by collision-induced dissociation tandem mass spectrometry. Product ion spectra were manually or using either the online form of the MASCOT program (searching against the nonredundant MSDB database) or a licensed version of this program against a private snake venom database comprising 927 sequence entries (212 in SwissProt, 715 in TrEMBL) plus the previously assigned peptide ion sequences from snake venomics projects carried out in our laboratory [9-14]. Fig. 5B illustrates the de novo sequencing of a doubly-charged tryptic peptide ion ( $\mathrm{m} / \mathrm{z}$ 774.1) from protein Lm29 (Figs. 1 and 2) identified as an L-amino acid oxidase (Table 1). The outlined snake venomics approach allowed us to assign unambiguously all the isolated venom toxins representing more than $0.05 \%$ of the total venom proteins (i.e. less than $50 \mathrm{ng}$ in $100 \mu \mathrm{g}$ of venom proteins) to known protein families (Tables 1 and 2).

Supporting the view that venom proteomes are mainly composed of toxins belonging to a few protein families $[4,9-$ 14,16-24], the proteins found in the venoms of L. muta and L. stenophrys cluster, respectively, in 8 and 7 different families (bradykinin-potentiating peptides, NGF, PLA 2 , serine proteinase, cysteine-rich secretory proteins (CRISP; only found in L. muta), C-type lectins, L-amino acid oxidase (LAO), and $\mathrm{Zn}^{2+}$ dependent metalloproteinases) (Fig. 6), whose relative abundances are listed in Table 3. 
Table 2 - Assignment of the reverse-phase fractions of Lachesis stenophrys venom (Costa Rica), isolated as in , to protein families by N-terminal Edman sequencing, mass spectrometry, and collision-induced fragmentation by nESI-MS/MS of selected peptide ions from in-gel digested protein bands (separated by SDS-PAGE as in

\begin{tabular}{|c|c|c|c|c|c|c|}
\hline \multirow[t]{2}{*}{ HPLC fraction } & \multirow[t]{2}{*}{$\mathrm{N}$-terminal sequencing } & \multirow{2}{*}{$\begin{array}{l}\text { Isotope- } \\
\text { averaged } \\
\text { molecular } \\
\text { mass }\end{array}$} & \multicolumn{2}{|c|}{$\begin{array}{l}\text { Peptide } \\
\text { ion }\end{array}$} & \multirow[t]{2}{*}{$\begin{array}{l}\text { MS/MS-derived } \\
\text { sequence }\end{array}$} & \multirow[t]{2}{*}{ Protein family } \\
\hline & & & $m / z$ & $\mathrm{z}$ & & \\
\hline 1 & N.D. & 480.6 & & 2 & ZKKWPPGH & [Q27J49] \\
\hline \multirow[t]{2}{*}{2} & N.D. & 532.4 & & 2 & TPPAGPDVGPR & [Q27J49] \\
\hline & & 482.1 & & 2 & PPAGPDVGPR & \\
\hline 3,4 & n.p. & & & & & \\
\hline \multirow[t]{4}{*}{5} & N.D. & 702.8 & & 2 & ZKKWPPGHHIPP & [Q27J49] \\
\hline & & 710.5 & & 2 & QKKWPPGHHIPP & \\
\hline & & 549.0 & & 2 & ZKKWPPGHH & \\
\hline & & 530.1 & & 2 & WPPGHHIPP(+41) & \\
\hline \multirow[t]{2}{*}{6} & N.D. & 639.1 & & 2 & ZEWPPGHHIPP & [Q27J49] \\
\hline & & 622.1 & & 2 & PRPQIPPLVVQ & \\
\hline \multirow[t]{3}{*}{7} & N.D. & 748.4 & & 2 & SHKGWPPRPQIPP & [Q27J49] \\
\hline & & 572.9 & & 2 & GWPPRPQIPP & \\
\hline & & 649.8 & & 2 & WPPRPQIPPLV & \\
\hline \multirow[t]{2}{*}{8} & N.D. & 623.1 & & 2 & ZKWDPPPISPP & [Q27J49] \\
\hline & & 543.4 & & 2 & WPPRPQIPP & \\
\hline 9 & GDGCFGLKLDRIGSMSGLGC & 1983.1 & & & & C-NP [Q27J49] \\
\hline \multirow[t]{3}{*}{10} & Blocked & $16 \mathrm{kDa} \cdot \boldsymbol{\nabla}$ & 556.2 & 2 & NPNPVPTGCR & Nerve growth factor \\
\hline & & & 632.1 & 2 & IDAACVCISR & \\
\hline & & & 682.1 & 2 & ALTMEGNQASWR & \\
\hline 11 & N.D. & $15 \mathrm{kDa} \boldsymbol{\nabla}$ & 649.6 & 2 & HLLQFGDLIDK & $\mathrm{PLA}_{2}$ \\
\hline 12 & HLLQFGDLIDKIAGR & 14052 & 649.7 & 2 & HLLQFGDLIDK & $\mathrm{PLA}_{2}$ \\
\hline \multirow[t]{3}{*}{13} & HLLQFGDLIDKIAGR & 13898 & 649.7 & 2 & HLLQFGDLIDK & $\mathrm{PLA}_{2}$ \\
\hline & & & 753.3 & 2 & CCFVHDCCYGK & \\
\hline & & & 605.4 & 3 & EICECDRDAAICFR & \\
\hline \multirow[t]{3}{*}{14} & IIGGDECNINEHRFL & $37 \mathrm{kDa} \cdot \boldsymbol{\nabla}$ & 647.7 & 2 & XNXXDYEVCR & Serine proteinase \\
\hline & & & 763.8 & 2 & IIGGDECNINEHR & \\
\hline & & $13 \mathrm{kDa}^{\nabla}$ & & & & \\
\hline 15 & (V/I)(V/I)GGDECNINEHRFL & $34 \mathrm{kDa} \nabla \boldsymbol{\nabla}$ & 647.7 & 2 & XNXXDYEVCR & Serine proteinase \\
\hline & & & 763.8 & 2 & IIGGDECNINEHR & \\
\hline & & & 621.9 & 2 & TGXWGXR & \\
\hline 16 & (V/I)(V/I)GGDECNINEHRFL & $32 \mathrm{kDa}=\boldsymbol{\nabla}$ & 756.8 & 2 & VIGGDECNINEHR & Serine proteinase \\
\hline & & & 683.4 & 2 & (292.2)PEFGLPATSR & \\
\hline & & & 715.3 & 2 & SXPSSPPSVGSVCR & \\
\hline 17 & M: NNCPQDWLPMNGLCY & $28 \mathrm{kDa}$ - & 670.6 & 3 & NNCPQDWLPMNGLCYK & Gal-lectin [Q9PSM4] \\
\hline & & $14 \mathrm{kDa} \nabla$ & 639.6 & 3 & YGESLEIAEYISDYHK & \\
\hline & & & 786.8 & 2 & EFCVELVSLTGYR & \\
\hline & & & 736.8 & 2 & YKPGCHLASFHR & \\
\hline & & & 701.3 & 2 & GQAEVWIGLWDK & \\
\hline & & & 765.4 & 2 & GQAEVWIGLWDKK & \\
\hline & & & 657.7 & 2 & AWEDAEMFCR & \\
\hline & & & 621.1 & 2 & DFSWEWTDR & \\
\hline & & & 685.3 & 2 & KDFSWEWTDR & \\
\hline & & & 800.8 & 2 & KYKPGCHLASFHR & \\
\hline & m: VIGGDECNINEHRFL & $34 \mathrm{kDa} \nabla$ & & & & Serine proteinase \\
\hline 18 & IVGGDECNINEHRFL & $34+26 \mathrm{kDa} \nabla$ & 756.9 & 2 & IVGGDECNINEHR & Serine proteinase \\
\hline & & & 711.5 & 2 & AIYPEFGLPATSR & \\
\hline 19 & N.D. & $29 \mathrm{kDa}=\boldsymbol{\nabla}$ & 690.4 & 2 & (306.4)PEFGLPATSR & Serine proteinase \\
\hline 20 & VLGGDECNINEHRFL & $33+24 \mathrm{kDa} \nabla$ & 715.3 & 2 & SLPSSPPSVGSVCR & Serine proteinase \\
\hline & & & 647.7 & 2 & XNXXDYEVCR & \\
\hline 21 & VIGGDECNINEHRSLVALYD & $38 \mathrm{kDa}=\boldsymbol{\nabla}$ & 575.5 & 2 & NVKFDDEQR & Ser-proteinase Venombin A \\
\hline & & & 756.9 & 2 & VIGGDECNINEHR & (S35689) \\
\hline & & & 867.3 & 2 & VLCAGVLEGGIDTCNR & \\
\hline & & & 710.9 & 2 & SLMNIYLGMHNK & \\
\hline & & & 772.8 & 2 & SLPSNPPSEDSVCR & \\
\hline & VFGGDECNINEHRSLVVLFN & $31 \mathrm{kDa} \boldsymbol{\nabla}$ & 773.9 & 2 & VFGGDECNINEHR & Ser-proteinase (P84036) \\
\hline & & & 711.5 & 2 & AIYPEFGLPATSR & Plasminogen-activator \\
\hline 22 & VFGGDECNINEHRSLVV & $32 \mathrm{kDa} \nabla$ & 715.3 & 2 & SLPSSPPSVGSVCR & Serine proteinase \\
\hline & & & 647.7 & 2 & XNXXDYEVCR & \\
\hline & & & 690.4 & 2 & (306.4)PEFGLPATSR & \\
\hline & & & 773.9 & 2 & VFGGDECNINEHR & \\
\hline & VVGGDECNINEHR & $31 \mathrm{kDa} \nabla$ & 749.9 & 2 & VVGGDECNINEHR & Serine proteinase \\
\hline
\end{tabular}




\section{Table 2 (continued)}

\begin{tabular}{|c|c|c|c|c|c|c|}
\hline \multirow{2}{*}{$\begin{array}{l}\text { HPLC fraction } \\
\text { Ls- }\end{array}$} & \multirow[t]{2}{*}{$\mathrm{N}$-terminal sequencing } & \multirow{2}{*}{$\begin{array}{l}\text { Isotope- } \\
\text { averaged } \\
\text { molecular } \\
\text { mass }\end{array}$} & \multicolumn{2}{|c|}{$\begin{array}{l}\text { Peptide } \\
\text { ion }\end{array}$} & \multirow[t]{2}{*}{$\begin{array}{l}\text { MS/MS-derived } \\
\text { sequence }\end{array}$} & \multirow[t]{2}{*}{ Protein family } \\
\hline & & & $m / z$ & $\mathrm{z}$ & & \\
\hline \multirow[t]{5}{*}{23} & \multirow[t]{5}{*}{ N.D. } & \multirow[t]{5}{*}{$32 \mathrm{kDa} \nabla$} & 488.2 & 2 & ETYPNVPR & \multirow[t]{5}{*}{ Serine proteinase } \\
\hline & & & 618.8 & 2 & XNXXDYAVCR & \\
\hline & & & 744.6 & 2 & (261.2)PSSPPSVGSVCR & \\
\hline & & & 791.8 & 2 & CANXNXXDYXVCR & \\
\hline & & & 824.8 & 2 & NDTEWDKDXMXXR & \\
\hline \multirow[t]{3}{*}{24,25} & \multirow[t]{3}{*}{ ADDRNPLGECFRETDYEEFL } & \multirow[t]{3}{*}{$58 \mathrm{kDa} \cdot \boldsymbol{\nabla}$} & 583.1 & 2 & KFWEDDGIR & \multirow[t]{3}{*}{ L-amino acid oxidase } \\
\hline & & & 641.0 & 2 & SAGQLYEESLGK & \\
\hline & & & 744.0 & 2 & ETDYEEFLEIAK & \\
\hline 26 & N.D. & $110+52 \mathrm{kDa} \nabla \boldsymbol{\nabla}$ & 532.3 & 2 & YNGNXNTXR & PIII-metalloproteinase \\
\hline \multirow[t]{5}{*}{27} & \multirow[t]{5}{*}{ N.D. } & $52 \mathrm{kDa}=\mathbf{\nabla}$ & 532.3 & 2 & YNGNXNTXR & PIII-metalloproteinase \\
\hline & & \multirow[t]{2}{*}{$27 \mathrm{kDa}^{\nabla}$} & 605.3 & 2 & DYYEMFXTK & \multirow[t]{2}{*}{ PI-metalloproteinase } \\
\hline & & & 640.8 & 2 & NSVGXVQDHSPK & \\
\hline & & \multirow[t]{2}{*}{$15 \mathrm{kDa}^{\nabla}$} & 621.3 & 2 & DFSWEWTDR & \multirow[t]{2}{*}{ Gal-lectin [Q9PSM4] } \\
\hline & & & 786.9 & 2 & EFCVELVSTGYR & \\
\hline \multirow[t]{7}{*}{$28-31$} & \multirow{7}{*}{ Blocked } & \multirow{7}{*}{$27 \mathrm{kDa}^{\boldsymbol{\nabla}}$} & 802.6 & 2 & VHEXVNTXNVFYR & \multirow{7}{*}{$\begin{array}{l}\text { PI-metalloproteinase } \\
\sim \text { (P22796) }\end{array}$} \\
\hline & & & 605.3 & 2 & DYYEMFXTK & \\
\hline & & & 540.3 & 2 & TFGEWRER & \\
\hline & & & 640.8 & 2 & NSVGXVQDHSPK & \\
\hline & & & 861.5 & 2 & YXEXVVVADHGMFTK & \\
\hline & & & 532.8 & 2 & YNGNXNTXR & \\
\hline & & & 683.4 & 3 & TLLIAVTMAHELGHNLGMK & \\
\hline \multirow[t]{3}{*}{29} & \multirow[t]{3}{*}{ Blocked } & \multirow[t]{3}{*}{$52 \mathrm{kDa} \bullet \nabla$} & 526.7 & 2 & GNYYGYCR & \multirow[t]{3}{*}{ PIII-metalloproteinase } \\
\hline & & & 801.3 & 2 & MYEXANTVNDXYR & \\
\hline & & & 684.8 & 3 & XTVKPEAGYTXNAFGEWR & \\
\hline 30 & Blocked & $\begin{array}{l}110 \mathrm{kDa} \\
48 \mathrm{kDa} \nabla\end{array}$ & 635.8 & 2 & XYCFPSSPATK & (PIII-Metalloproteinase) ${ }_{2}$ \\
\hline 31 & Blocked & $52 \mathrm{kDa} \cdot \boldsymbol{\nabla}$ & 506.2 & 2 & FTSAGNVCR & PIII-metalloproteinase \\
\hline & & & 650.2 & 2 & YVEXVVVADHR & \\
\hline & & & 752.4 & 2 & XFEFNNFPCR & \\
\hline 32 & N.D. & $110 \mathrm{kDa}$ - & 752.4 & 2 & XFEFNNFPCR & (PIII-Metalloproteinase) ${ }_{2}$ \\
\hline & & $52 \mathrm{kDa} \nabla$ & 506.2 & 2 & FTSAGNVCR & \\
\hline
\end{tabular}

$\mathrm{X}$, Ile or Leu; Z, pyrrolidone carboxylic acid; Ac-, N-acetyl; $m$, methionine sulphoxide. Unless other stated, for MS/MS analyses, cysteine residues were carbamidomethylated. Molecular masses of native proteins were determined by electrospray-ionization $( \pm 0.02 \%)$ or MALDI-TOF $(*)( \pm 0.2 \%)$ mass spectrometry. Apparent molecular mass determined by SDS-PAGE of non-reduced ( $\boldsymbol{\square})$ and reduced $(\boldsymbol{\nabla})$ samples; n.p., non-peptidic material found. $\mathrm{M}$ and $\mathrm{m}$, denote mayor and minor products co-eluting in the same HPLC fraction. Previously reported proteins are identified by their databank accession codes.

Except for the absence of a CRISP molecule in the venom of L. stenophrys, the two Lachesis species investigated show very similar overall venom toxin compositions (Table 3). However, comparison of the chromatographic separations of the venom proteins from L. muta and L. stenophrys (Figs. 1 and 3) and the tryptic peptide mass fingerprints of their individual protein bands (Tables 1 and 2), evidenced both, a number of very similar (or identical) proteins but also toxins from the same family showing a large degree of structural divergence.

Identical L. muta and L. stenophrys venom components include a number of bradykinin-potentiating peptides (BPPs) and a C-type natriuretic peptide released from the 239-aminoacid precursor protein Q27J49 (Fig. 7). BPPs found in fractions Ls7, Lm9/Ls6, Lm6/Ls5, and Lm10/Ls8 have been previously identified by MALDI-TOF MS in the crude venom of a specimen kept in captivity at the serpentarium of the Fundação Ezequiel Dias (Belo Horizonte, Brazil) [35], indicating that expression of these peptides appear not to exhibit geographical variation. BPPs have been described as snake venom inhibitors of the angiotensin-converting enzyme, a dipeptidylcarboxypeptidase expressed in endothelial, epithelial and neuroepithelial cells, which converts inactive angiotensin I into the potent vasoconstrictor angiotensin II, and degrades bradykinin into bradykinin (1-7) or bradykinin (1-5) [36]. BPPs prevent the hypertensive effect of the angiotensin II and potentiate the hypotensive effect of the circulating bradykinin. C-natriuretic peptides elicit natriuretic, diuretic, and vasorelaxant activities. Lachesis protein Q27J49 encodes BPPs and a C-natriuretic peptide, combining in one precursor molecule two kinds of vasoactive molecules. Vasodilatation and hypotension contribute synergistically to overall venom toxicity evoking the rapid diffusion of toxic substances in the circulatory system and a hypotensive shock, which is a major cause of death of the prey or victim induced by viper snake bites. The BPPs were also essential for the development of the first commercial ACE inhibitor, captopril, for the treatment of human hypertension [37]. Although L. muta and L. stenophrys express similar relative amounts of BPPs into their venoms, each snake showed 


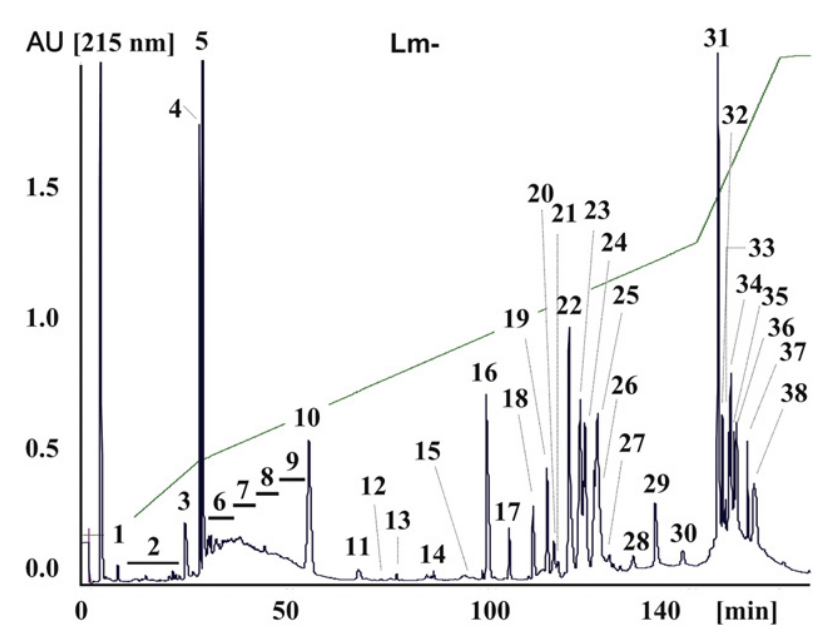

Fig. 1-Reverse-phase HPLC separation of the Lachesis muta venom proteins. Two milligrams of Lachesis muta venom (Santa Cruz de la Sierra, Bolivia) were applied to a Lichrosphere RP100 C 18 column, which was then developed with the following chromatographic conditions: isocratically (5\% B) for $10 \mathrm{~min}$, followed by $5-15 \%$ B for $20 \mathrm{~min}, 15-45 \%$ B for $120 \mathrm{~min}$, and $\mathbf{4 5 - 7 0 \% ~ B ~ f o r ~} 20 \mathrm{~min}$. Fractions were collected manually and characterized by $\mathrm{N}$-terminal sequencing, ESI mass spectrometry, tryptic peptide mass fingerprinting, and CID-MS/MS of selected doubly- or triply-charged peptide ions. The results are shown in Table 1.

distinct complements of Q27J49-derived peptides, suggesting that the processing steps required to form the mature BPPs are overlapping though not identical in the two Lachesis species. However, whether the occurrence of distinct sets of BPPs reflects an evolutionary adaptation or merely a neutral consequence of speciation deserves further detailed investigations.

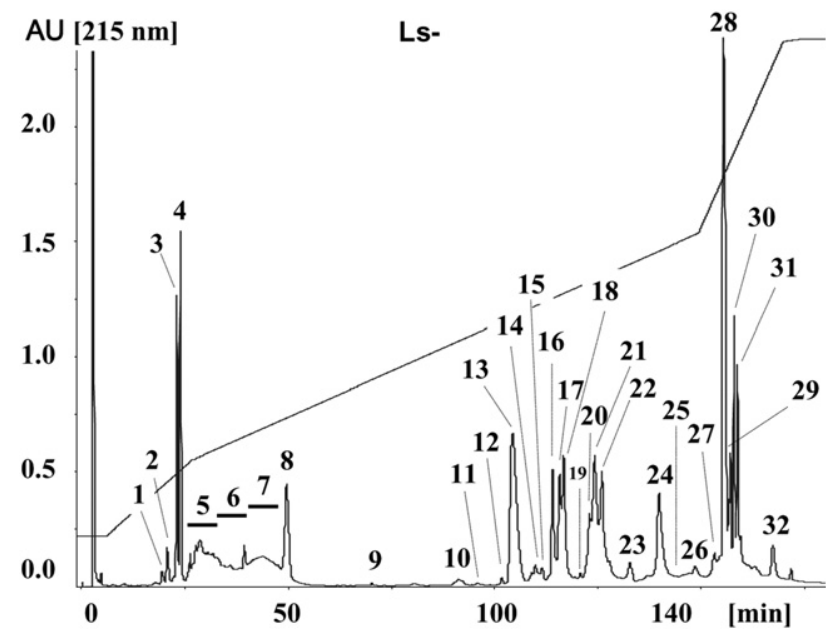

Fig. 3-Reverse-phase HPLC separation of the venom proteins of Lachesis stenophrys. Two milligrams of L. stenophrys venom (Costa Rica) were applied to a Lichrosphere RP100 $\mathrm{C}_{18}$ column, which was then developed as in Fig. 1. Fractions were collected manually and characterized by $\mathrm{N}$-terminal sequencing, ESI mass spectrometry, tryptic peptide mass fingerprinting, and CID-MS/MS of selected doubly- or triply-charged peptide ions. The results are shown in Table 2.

Through the pathophysiological consequences of the presence of large amounts of BPPs in Lachesis venoms deserve further and detailed consideration, the large content of BPPs in the two Lachesis venoms investigated may be associated with the conspicuous hypotension of very rapid onset which characterizes bushmaster envenomation cases, an effect that is likely to contribute to hemodynamic complications leading to cardiovascular shock [27].

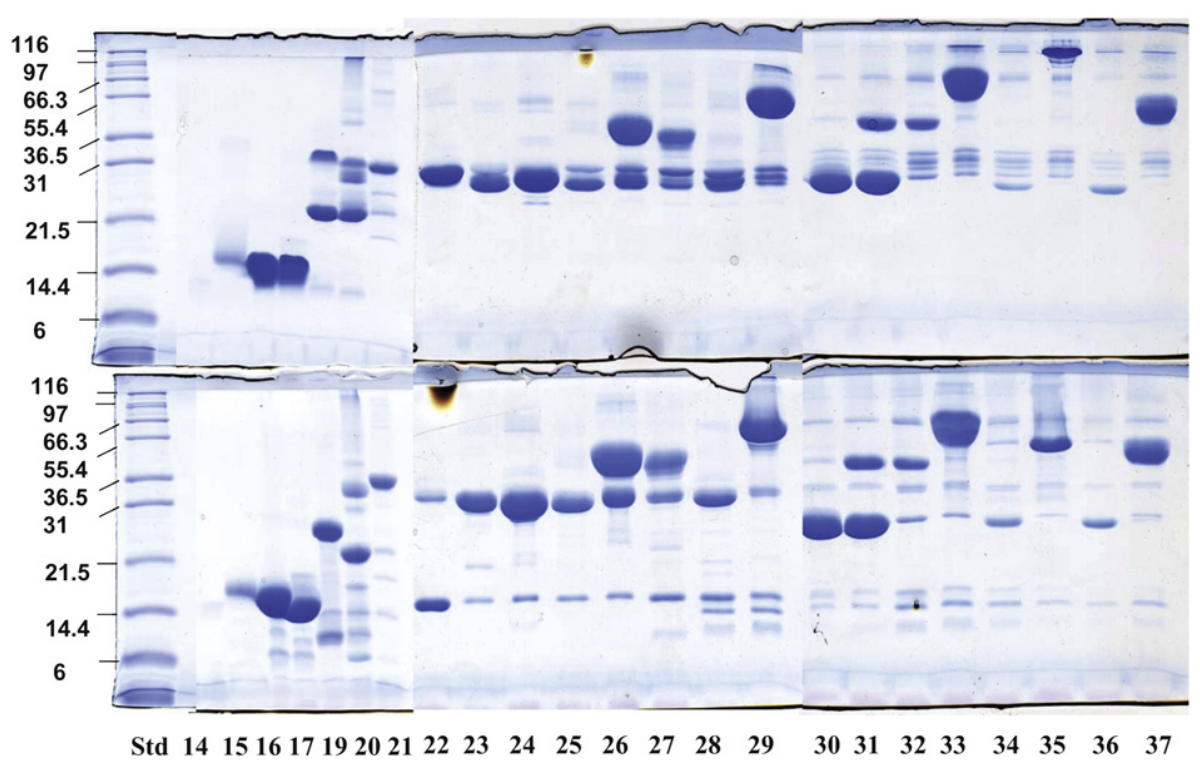

Fig. 2-SDS-PAGE of reverse-phase separated fractions from the venom of Lachesis muta (Santa Cruz de la Sierra, Bolivia). SDS-PAGE showing the protein composition of the reverse-phase HPLC separated venom protein fractions run under non-reduced (panel A) and reduced (panel B) conditions. Molecular mass markers (in $\mathrm{kDa}$ ) are indicated at the left of each gel. Protein bands were excised and characterized by mass fingerprinting and CID-MS/MS. The results are shown in Table 1. 


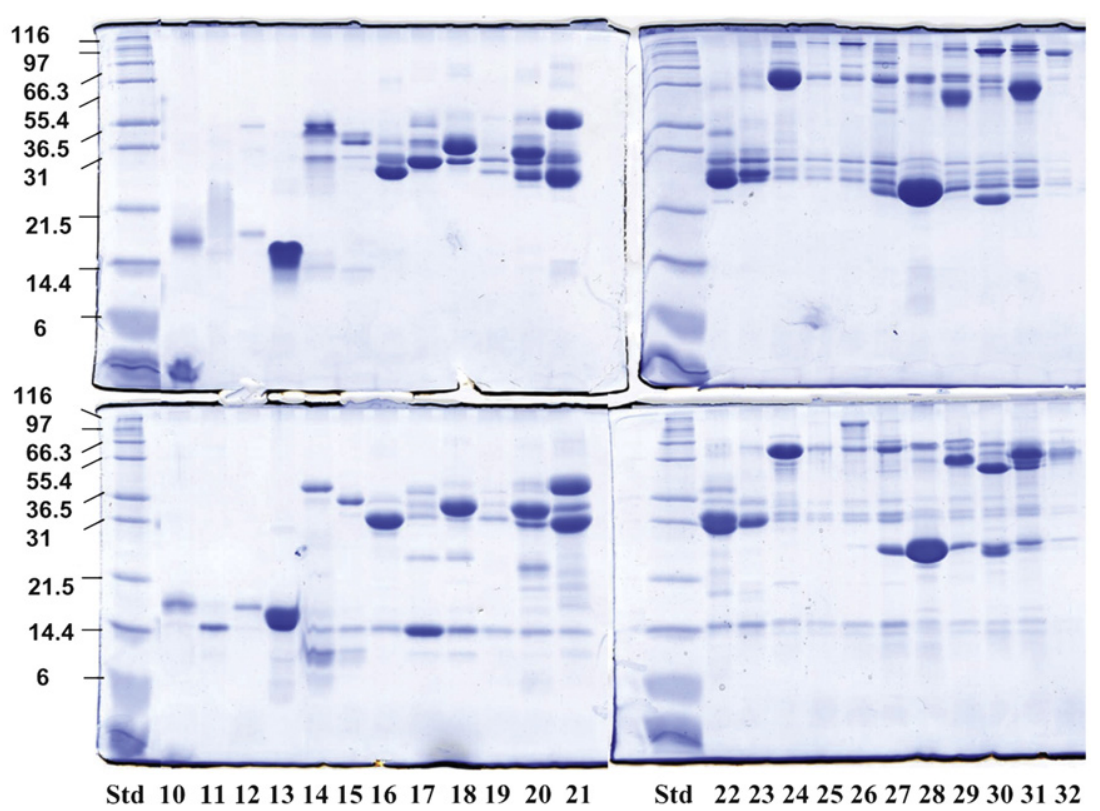

Fig. 4-SDS-PAGE of reverse-phase separated fractions from the venom of Lachesis stenophrys (Costa Rica). SDS-PAGE showing the protein composition of the reverse-phase HPLC separated venom fractions (see Fig. 3) run under non-reduced (panel A) and reduced (panel B) conditions. Molecular mass markers (in $\mathrm{kDa}$ ) are indicated at the left of each gel. Protein bands were excised and characterized by mass fingerprinting and CID-MS/MS. The results are shown in Table 2.

Furthermore, the low molecular mass of these peptides is likely to confer them with very low antigenicity, with the consequent implications for antivenom development. It would be relevant to assess whether antivenoms are effective at binding and neutralizing BPPs present in Lachesis venoms.

Other very similar or identical proteins in L. muta and L. stenophrys venoms, based on their similar chromatographic
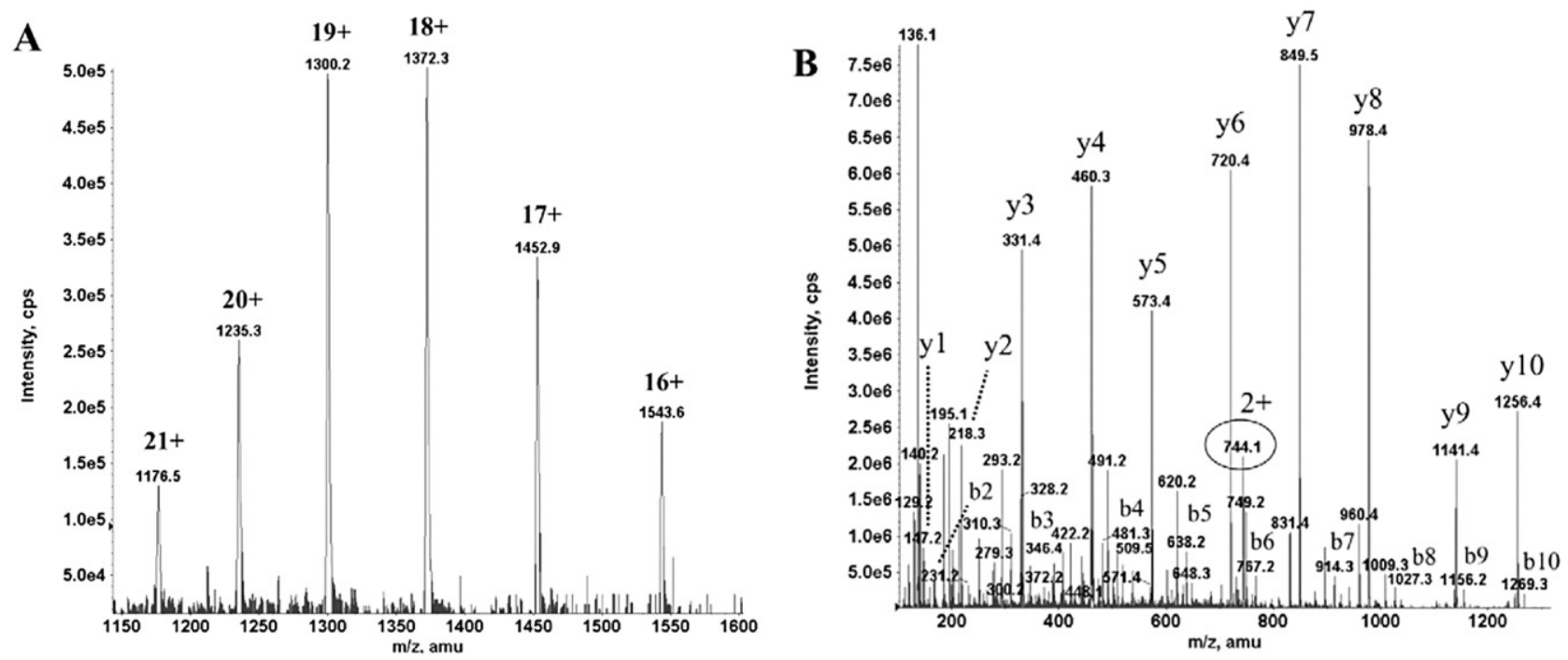

Fig. 5-Mass spectrometric characterization of isolated proteins and tryptic peptides. (A) Electrospray-ionization mass spectrum of the major protein isolated in HPLC fraction 18 (Figs. 1 and 2, Table 1). From the series of ions $(\mathrm{M}+16 \mathrm{H})^{16+}-(\mathrm{M}+21 \mathrm{H})^{21+}$ an isotope-averaged molecular mass of $24683.9 \pm 2.1 \mathrm{Da}$, and was identified by $\mathrm{N}$-terminal sequencing as a member of the CRISP family. (B) MS/MS spectrum of the doubly-charged tryptic parent ion of $\mathrm{m} / \mathrm{z} 744.1$ (encircled) from the $58 \mathrm{kDa}$ protein isolated in fraction Lm29 of Lachesis muta venom HPLC separation (Figs. 1 and 2, Table 1). Ions of the major sequence-specific y-ion series and of a minor series of the complementing b-ions, from which the sequence (231.2) DYEEFXEXAK sequence tag was deduced, are labelled. This sequence is present as ETDYEEFLEIAK in the $\mathbf{N}$-terminal sequence of the $58 \mathrm{kDa}$ parent protein identified as an L-amino acid oxidase (Table 1). 
A

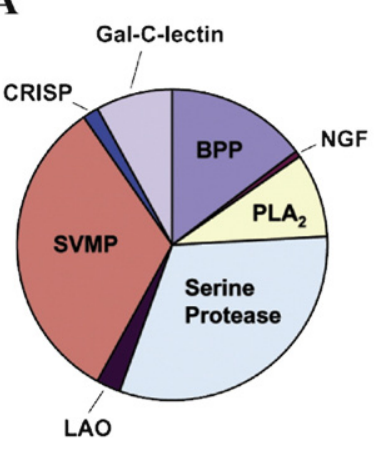

B

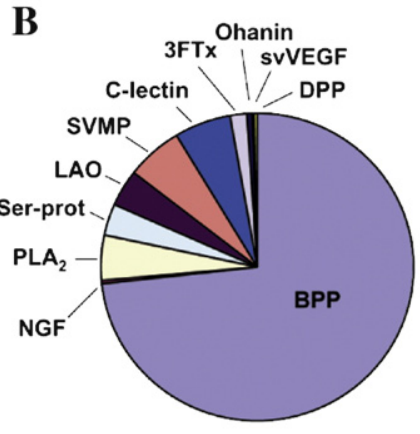

C

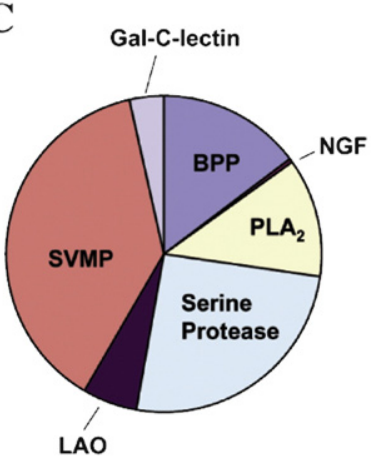

Fig. 6-Proteomics and transcriptomics of Lachesis venoms. Comparison of the protein composition of the venoms of Lachesis muta (A) and Lachesis stenophrys (C) determined using a proteomic (this work) and a transcriptomic (panel B) approach [23]. BPP, bradykinin-potentiating/C-natriuretic peptide; NGF, nerve growth factor; LAO, L-amino acid oxidase; PLA 2 , phospholipase $A_{2}$; SVMP, snake venom metalloproteinase; SVVEGF, snake venom vascular endothelial growth factor; CRISP, cysteine-rich secretory protein; Gal-lectin, galactose-specific lectin; Ser-Prot, serine proteinase; 3FTx, three-finger toxin; DPP, dipeptidylpeptidase.

retention time and molecular masses and by sharing tryptic ions include the nerve growth factor isolated in fractions Lm15 and Ls10; the serine proteinase Q27J47 isolated in fractions Lm20 and Ls14/15, as well as the thrombin-like enzime venombin A [S35689] and the plasminogen-activating proteinase P84036, both eluted in HPLC fractions Lm26 and Ls21; the galactose-specific lectin Q9PSM4; the L-amino acid oxidase characterized in fraction Lm29 and Ls24; and the major PI-metalloproteinase, hemorrhagic factor LHFII [P22796].

Based on phylogenetic hypothesis, published morphological and behavioral differences, and the allopatric distributions of distinctive population groups, Zamudio and Green elevated L. muta and L. stenophrys to species level in 1997 [38]. They estimated that the Central and South American forms diverged 18-6 Mya, perhaps due to the uplifting of the Andes. As judged from the protein chemical and mass spectrometric data listed in Tables 1 and 2, each Lachesis venom may contain 24-26 different gene products. Using a similarity coefficient (PSC), we estimate that L. muta and L. stenophrys share only 8 proteins. Such a low figure (PSC=30-32\%) highlight the rapid structural diversification of venom toxins of closely related congeneric taxa.

Table 3 - Overview of the relative occurrence of proteins of the different toxin families in the venoms of Lachesis muta and Lachesis stenophrys

Protein family

$\%$ of total venom proteins

Lachesis muta Lachesis stenophrys

\begin{tabular}{lrl}
\hline BPP/C-NP & 14.7 & 14.6 \\
Nerve growth factor & 0.6 & 0.4 \\
PLA $_{2}$ & 8.7 & 12.3 \\
CRISP & 1.8 & - \\
Serine proteinase & 31.2 & 25.6 \\
Gal-lectin/C-type lectin-like & 7.9 & 3.6 \\
L-amino acid oxidase & 2.7 & 5.3 \\
Zn $^{2+}$-metalloproteinase & 31.9 & 38.2 \\
\hline
\end{tabular}

\subsection{Proteomic vs. transcriptomic of L. muta venom}

Comparison of the protein composition of the venom of L. muta determined using a proteomic (this work) and a transcriptomic approach [23] shows clear differences, both in the relative occurrence of protein families (expressed as percentages of the total HPLC-separated proteins) (Fig. 6) and in the identity of the polypeptides of each protein family. It is worth to notice that only 6 venom proteins matched any of the previously reported 11 partial or full-length venom gland transcripts [23]. On the other hand, 16 L. muta venom components correspond to proteins not reported in the databasedeposited transcriptome of the same species [23]. This set of novel proteins comprise both minor components, i.e. the $17 \mathrm{kDa}$ nerve growth factor (Lm15) and the C-type lectin(s) spread in fractions 28-38, and relatively abundant proteins, such as all the venom-secreted PLA $\mathrm{A}_{2}$ molecules (Lm16-18), the CRISP molecule found in venom fractions Lm18-20, several serine proteinases (Lm20, Lm24, and Lm28), the single $52 \mathrm{kDa}$ $\mathrm{L}$-amino acid oxidase found in fraction Lm29, and a number of snake venom metalloproteinases of the PI and PIII classes of the reprolysin family (Lm32-38) (Table 1). The low degree of venom composition accordance between the proteomic and the transcriptomic approaches has been also reported for B. gabonica [13], and clearly indicate that the cDNA library lacked many transcripts encoding venom-expressed proteins. On the other hand, in some cases the lack of correspondence between the proteomic and the transcriptomic data may be due to the unavailability of the cDNA-deduced protein sequences in the public-accessible databases. Hence, Junqueirade-Azevedo et al. [23] reported the cloning of two almost identical cDNA clusters coding for an L-amino acid oxidases (comprising $3.7 \%$ of the total toxin-coding ESTs), which matched LAOs from other Viperidae species over the entire $2705 \mathrm{bp}$ extension and which may correspond to the L. muta LAO identified earlier by Sanchez and Magalhães [39]. Similarly, Junqueira-de-Azevedo et al. [23] also found clusters coding for single forms of nerve growth factor (NGF; $0.3 \%$ of total toxin-coding ESTs) and snake venom vascular 


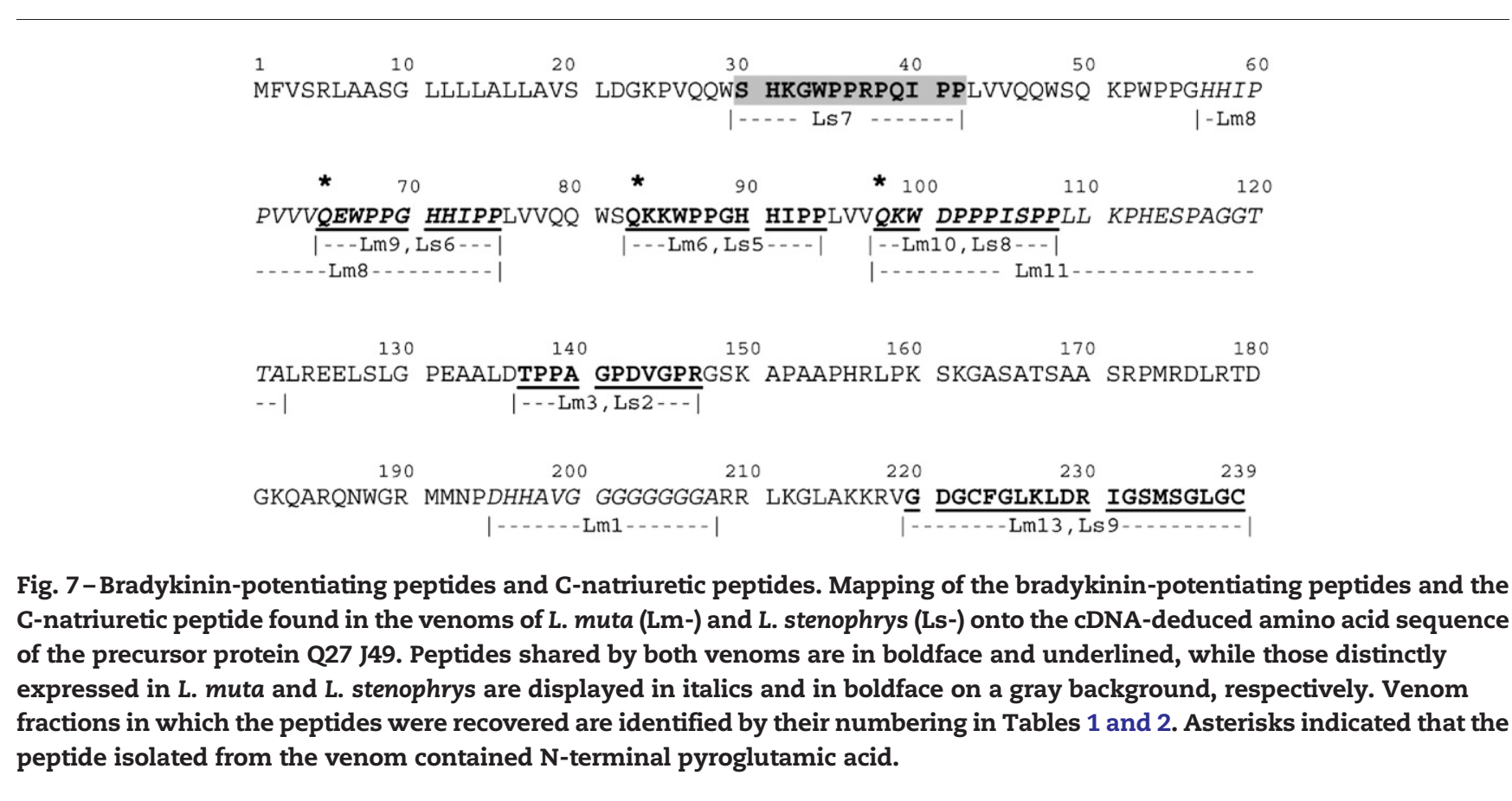

endothelial growth factor (svVEGF) in their reported L. muta transcriptome, although their sequences are not available in the non-redundant SwissProt/TrEML and NCBI databanks. However, in those venoms in which LAO and growth factors have been identified, these toxins appear to be expressed as single components, suggesting that they may represent products of single copy genes, and thus that the proteomic and the transcriptomic approach may match the same venom components.

Transcripts encoding putative secreted toxin classes [23], which were not be found in our proteomic analysis include three finger-like toxins [Q27J50], ohanin-like protein [Q27J48], svVEGF, and dipeptidyl peptidase. In addition, neither L. muta nor L. stenophrys venom contained detectable amounts of lachesin, a medium-size disintegrin [P31990] isolated from lyophilized venom of L. muta of non-reported origin purchased from Miami Serpentarium Laboratories (Salt Lake City, UT) [40]. The occurrence of non-venom-secreted toxins suggests that these messengers could exhibit an individual or a temporal expression pattern over the life time of the snake. Sex-based individual variation of snake venom proteome among B. jararaca siblings have been reported [41]. In addition, ontogenetic and geographical variations have been noticed in the venom proteomes of other snakes, i.e. Crotalus viridis viridis [42], C.v. oreganus [43,44], Bothrox atrox $[45,46]$, and Bothrops asper [46], and might represent a common phenomenon in many other species (see below). Alternatively, the nonvenom-secreted or very low abundance $(<0.05 \%$ of the total venom proteins), toxins may play a hitherto unrecognized physiological function in the venom gland, or may simply represent a hidden repertoire of orphan molecules which may eventually become functional for the adaptation of snakes to changing ecological niches and prey habits. Clearly, although further work is needed to clarify this point, overall, our results emphasize the relevance of detailed proteomic studies for a thorough characterization of the venom composition.
3.3. Intraspecific variation in venom-secreted $\mathrm{PLA}_{2}$ molecules

The PLA 2 molecules isolated in fractions 16-18 (Fig. 1, Table 1) display high $\mathrm{N}$-terminal sequence similarity to the hemolytic and platelet aggregation inhibitory Lm-PLA $A_{2}-\mathrm{I}$ and Lm-PLA $\mathrm{A}_{2}$-II characterized by Fully et al. [47] from L. muta venom provided by Sigma or Fundação Ezequiel Dias (FUNED, Brazil), to LMPA1 (P84651) from the same source, and to two basic neurotoxic Asp49 PLA $_{2}$ molecules (LmTX-I and LmTX-II) isolated from L. muta venom purchased from Sigma [48,49] (Table 4). In particular, the N-terminal sequence of the PLA $\mathrm{A}_{2}$ isolated in fraction Lm18 (Table 1) seems to be identical to that of LMPLA2-II, except for the striking lack of the serine residue at position 16. This residue is absolutely conserved in the structures of all known myotoxic PLA $\mathrm{P}_{2}$ molecules [50], strongly suggested that a gap at position 16 may represent a sequencing or a typographical error. Regardless of that, none of the other $\mathrm{PLA}_{2}$ isoenzymes reported in the literature could be matched to any of the PLA $\mathrm{P}_{2}$ molecules found in the venom of L. muta from the nature reserve Potrerillos del Guendá (Santa Cruz de la Sierra, Bolivia) sampled here (Table 4). This prompted us to investigate if the lack of identity could be due to geographic variations of L. muta venoms. To this end, the venoms of 5 specimens ( 3 from Bolivia and 2 from Peru) and the venom purchased from Sigma (unknown origin) were compared. Noteworthy, the 6 reverse-phase HPLC separations were essentially superimposable, except for quantitative and qualitative differences in $\mathrm{PLA}_{2}$ expression (Fig. 8, Table 4). Thus, each venom exhibited a distinct combination, and/or concentration, of the same three PLA 2 molecules (Lm16, Lm17, and Lm18) listed in Table 1. The most abundant PLA molecules in Bolivian specimens were Lm16 and Lm18, whereas $\mathrm{Lm} 17$ was the predominant $\mathrm{PLA}_{2}$ in Peruvian L. muta venoms (Fig. 8). The venom purchased from Sigma (of non-declared origin) displayed the "Bolivian $\mathrm{PLA}_{2}$ 
Table 4-Comparison and occurrence of PLA $\mathrm{A}_{2}$ molecules characterized in the venom proteomes of Lachesis muta from different sources

\begin{tabular}{|c|c|c|c|c|c|c|}
\hline \multirow[t]{2}{*}{$\mathrm{N}$-terminal sequence (Mass) } & \multicolumn{3}{|c|}{ Bolivia } & \multicolumn{2}{|c|}{ Peru } & \multirow[t]{2}{*}{ Sigma } \\
\hline & 1 & 2 & 3 & 1 & 2 & \\
\hline $\begin{array}{l}\text { HLLQFGDLINKIARRNGISYYG } \\
(13,932 \mathrm{Da})\end{array}$ & $\bullet(16)$ & - & $\bullet$ & & - & - \\
\hline $\begin{array}{l}\text { HLLQFGDLINKIARRNGISYYG } \\
(13,916 \mathrm{Da})\end{array}$ & $\bullet(17)$ & & & $\bullet$ & $\bullet$ & \\
\hline $\begin{array}{l}\text { HLLQFEQLIRKIAGRSGFRYYG } \\
(14,008 \mathrm{Da})\end{array}$ & $\bullet(18)$ & - & $\bullet$ & & & $\bullet$ \\
\hline $\begin{array}{l}\text { SLFELGKMILQETGKNPAKSY } \\
(13,723 \mathrm{Da})\end{array}$ & & & & & & $\bullet$ (16a) \\
\hline HLLQFGDLIDKIAGRSGFWYYG & & & & & & \\
\hline PA2_LACMU (13,889 Da) & & & & & & \\
\hline HLLQFGDLIDKIAGRSGFWYYG & & & & & & \\
\hline LM-PLA2-I & & & & & & \\
\hline HLLQFEQLIRKIAGRGFRYYGF & & & & & & \\
\hline LM-PLA2-II & & & & & & \\
\hline HLLQFNKMIKFETRKNAIPFYAF & & & & & & \\
\hline LM-TX-I (14245 Da) & & & & & & \\
\hline HLLQFNKMIKFETRKNAIPFYAF & & & & & & \\
\hline LM-TX-II (14186 Da) & & & & & & \\
\hline
\end{tabular}

Bolivia-1 corresponds to the venom analyzed in detailed in Table 1. Numbers in parentheses indicate the reverse-phase HPLC fraction of Figs. 1 and 7 containing the corresponding PLA molecules. $^{2}$ $\mathrm{N}$-terminal sequences and, when available, the molecular mass of $\mathrm{PLA}_{2}$ proteins characterized previously from venoms of $\mathrm{L}$. muta specimens kept in captivity at the Fundação Ezequiel Dias (Belo Horizonte, Brazil) (PA2_LACMU, LM-PLA2-I, and LM-PLA2-II) or isolated from $L$. muta venom purchased from Sigma (LmTX-I and LmTX-II), are displayed. remote tropical rainforests. The recorded cases [27,57-60] are characterized by local and systemic manifestations typical of viperid venoms. Local effects include pain, edema, and hemorrhage, with the development of blisters. Systemic manifestations include coagulopathy and widespread bleeding. In some cases, a 'parasympathomimetic-like' effect has been described, with bradicardia, abdominal colics, nausea and vomiting [60]. These latter effects have been described in South American cases, but not in those occurred in Central America. Our detailed proteomic analysis of the venoms of Lachesis species supports the hypothesis that snake venom proteomes are composed of proteins belonging to only a few toxin families exhibiting structural divergence and distinct relative abundances in even closely related species. However, there does not appear to be a simple relationship between venom composition and the presence or absence of the described 'parasympathomimetic-like' effect. Because species-specific effects of venom components are largely unknown, it is difficult to assign a functional role unequivocally to the variation we observed in Lachesis venoms. Subtle functional differences in some venoms components, which may confer distinct pharmacological activities to proteins from the same family but distinctly expressed in L. muta and L. stenophrys, may be responsible for speciesspecific effects. Our proteomic analysis may serve as a starting point for studying structure-function correlations of individual toxins aiming at the development of new research tools and drugs of potential clinical use [61-63]. It is also worth to notice that though intraspecific variation in venom toxins may inform us about evolutionary processes acting at the species or population level, it represents also a source of signature" (Lm16+Lm18) but departed from the Bolivian and Peruvian venom-secreted $\mathrm{PLA}_{2}$ profiles in expressing a unique $\mathrm{PLA}_{2}$ molecule (labelled 16a in Fig. 8) with identical N-terminal sequence and very similar isotope-averaged molecular mass $(13723 \mathrm{Da})$ as myotoxic PLA 2 molecules from $B$. jararacussu (AAO27453; $13714 \mathrm{Da})$ [18], B. pirajai (1QLL_A; $13744 \mathrm{Da})$, and B. asper (P24605; 13,725 Da). As a whole, these results point out to a high degree of intraspecific variability in the expression of phospholipases $A_{2}$ in L. muta venoms. Intraspecific variability of $\mathrm{PLA}_{2}$ loci has been reported in other viperid (Vipera palestinae [51]) and crotalid (B. asper [52]; Trimeresurus flavoviridis [53]) species, and this phenomenon is often linked to differences in diet among populations [53,54].

Snake venom phospholipase $A_{2}$ genes are members of a large, rapidly-evolving multigene family with many diverse functions. Positive Darwinian selection is common in group-II viperid snake venom PLA $_{2}$ genes and is associated with the evolution of new toxin functions and speciation events [55]. Adaptive evolution of group-I phospholipases in elapids is also associated with speciation events [56], suggesting adaptation of the phospholipase arsenal to novel prey species after niche shifts.

\subsection{Concluding remarks}

Reports of envenomations by species of Lachesis are scarce, probably due to the fact that these species are distributed in
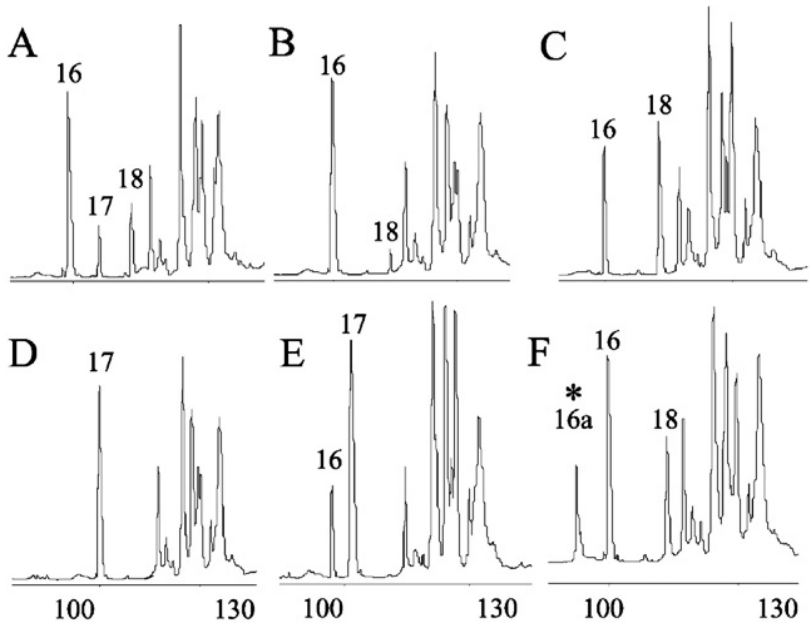

Fig. 8-Intraspecific variation in PLA2 isoenzyme venom composition. Panels A-F, details of the reverse-phase HPLC chromatograms of the venoms from Lachesis muta from Bolivia (A-C), Peru (D and E), and purchased from Sigma (F). Numbers refer to the reverse-phase HPLC separation shown in Fig. 1. Table 3 displays the $\mathrm{N}$-terminal sequences and molecular masses of the PLA $A_{2}$ molecules from the different sources. The peak 16a marked with asterisk in $F$ corresponds to a PLA 2 molecule specifically found in the venom sold by Sigma. 
concern in antivenom production strategies. Broad spectrum antivenoms may thus be prepared using pooled venoms. On the other hand, as knowledge of a particular group increases, its categorisation may need to be re-assessed. At this respect, the occurrence of intraspecific toxin composition variation in separated snake populations, as revealed in this and other works, suggests that polytypic species with a number of subspecies or races are more widespread than previously thought. Along with analysis of morphological traits, a detailed proteomic characterization of snake venoms may aid in establishing a taxonomic subdivision of snake species.

\section{Acknowledgement}

This study has been financed by grant BFU2004-01432/BMC from the Ministerio de Educación y Ciencia, Madrid, Spain, and Acciones Integradas CSIC-UCR 2006CR0010.

\section{R E F E R E N C E S}

[1] Fry BG, Wüster W. Assembling an arsenal: origin and evolution of the snake venom proteome inferred from phylogenetic analysis of toxin sequences. Mol Biol Evol 2004;21:870-83.

[2] Fry BG. From genome to "venome": molecular origin and evolution of the snake venom proteome inferred from phylogenetic analysis of toxin sequences and related body proteins. Genome Res 2005;15:403-20.

[3] Vidal N. Colubroid systematics: evidence for an early appearance of the venom apparatus followed by extensive evolutionary tinkering. J Toxicol Toxin Rev 2002;21:21-41.

[4] Fry BG, Vidal N, Norman JA, Vonk FJ, Scheib H, Ramjan SF, et al. Early evolution of the venom system in lizards and snakes. Nature 2006;439:584-8.

[5] Greene HW. Dietary correlates of the origin and radiation of snakes. Am Zool 1983;23:431-41.

[6] Fox JW, Serrano SMT, editors. Snake Toxins and Hemostasis, vol. 45. Toxicon; 2005. p. 951-1181.

[7] Markland FS. Snake venoms and the hemostatic system. Toxicon 1998;36:1749-800.

[8] Serrano SMT, Shannon JD, Wang D, Camargo AC, Fox JW. A multifaceted analysis of viperid snake venoms by two-dimensional gel electrophoresis: an approach to understanding venom proteomics. Proteomics 2005;5:501-10.

[9] Juárez P, Sanz L, Calvete JJ. Snake venomics: characterization of protein families in Sistrurus barbouri venom by cysteine mapping, $\mathrm{N}$-terminal sequencing, and tandem mass spectrometry analysis. Proteomics 2004;4:327-38.

[10] Bazaa A, Marrakchi N, El Ayeb M, Sanz L, Calvete JJ. Snake venomics: comparative analysis of the venom proteomes of the Tunisian snakes Cerastes cerastes, Cerastes vipera and Macrovipera lebetina. Proteomics 2005;5:4223-35.

[11] Sanz L, Gibbs HL, Mackessy SP, Calvete JJ. Venom proteomes of closely-related Sistrurus rattlesnakes with divergent diets. J Proteome Res 2006;5:2098-112.

[12] Juárez P, Wagstaff SC, Oliver J, Sanz L, Harrison RA, Calvete JJ. Molecular cloning of disintegrin-like transcript BA-5A from Bitis arietans venom gland cDNA library: a putative intermediate in the evolution of the long chain disintegrin bitistatin. J Mol Evol 2006;63:142-52.
[13] Calvete JJ, Marcinkiewicz C, Sanz L. Snake venomics of Bitis gabonica gabonica. Protein family composition, subunit organization of venom toxins, and characterization of dimeric disintegrins bitisgabonin-1 and bitisgabonin-2. J Proteome Res 2007;6:326-36.

[14] Calvete JJ, Escolano J, Sanz L. Snake venomics of Bitis species reveals large intragenus venom toxin composition variation: application to taxonomy of congeneric taxa. J Proteome Res 2007;6:2732-45.

[15] Ménez A, Stöcklin R, Mebs D. "Venomics" or: The venomous systems genome project. Toxicon 2006;47:255-9.

[16] Francischetti IM, My-Pham V, Harrison J, Garfield MK, Ribeiro JMC. Bitis gabonica (Gaboon viper) snake venom gland: towards a catalog of full-length transcripts (cDNA) and proteins. Gene 2004;337:55-69.

[17] Junqueira de Azevedo IL, Ho PL. A survey of gene expression and diversity in the venom glands of the pitviper snake Bothrops insularis through the generation of expressed sequence tags (ESTs). Gene 2002;299:279-91.

[18] Kashima S, Roberto PG, Soares AM, Astolfi-Filho S, Pereira JO, Giuliati S, et al. Analysis of Bothrops jararacussu venomous gland transcriptome focusing on structural and functional aspect: I-gene expression profile of highly expressed phospholipases $A_{2}$. Biochimie 2004;86:211-9.

[19] Cidade DAP, Simão TA, Dávila AMR, Wagner G, Junqueira-de-Azevedo ILM, Ho PL, et al. Bothrops jararaca venom transcriptome: analysis of the gene expression pattern. Toxicon 2006;48:437-61.

[20] Qinghua L, Xiaowei Z, Wei Y, Chenji L, Yijun H, Pengxin $\mathrm{Q}$ et al. A catalog for transcripts in the venom gland of the Agkistrodon acutus: identification of the toxins potentially involved in coagulopathy. Biochem Biophys Res Commun 2006;341:522-31.

[21] Zhang B, Liu Q, Yin W, Zhang X, Huang Y, Luo Y, et al. Transcriptome analysis of Deinagkistrodon acutus venomous gland focusing on cellular structure and functional aspects using expressed sequence tags. BMC Genomics 2006;7:152.

[22] Wagstaff SC, Harrison RA. Venom gland EST analysis of the saw-scaled viper, Echis ocellatus, reveals novel $\alpha_{9} \beta_{1}$ integrin-binding motifs in venom metalloproteinases and a new group of putative toxins, renin-like proteinases. Gene 2006;377:21-32.

[23] Junqueira-de-Azevedo ILM, Ching ATC, Carvalho E, Faria F, Nishiyama Jr MY, Ho PL, et al. Lachesis muta (Viperidae) CDNAs reveal diverging pitviper molecules and scaffolds typical of cobra (Elapidae) venoms: implications in snake toxin repertoire evolution. Genetics 2006;173:877-89.

[24] St Pierre L, Woods R, Earl S, Masci PP, Lavin MF. Identification and analysis of venom gland-specific genes from the coastal taipan (Oxyuramus scutellatus) and related species. Cell Mol Life Sci 2005;62:2679-93.

[25] Ching ATC, Rocha MMT, Leme AFP, Pimenta DC, Furtado MFD, Serrano SMT, et al. Some aspects of the venom proteome of the Colubridae snake Philodryas olfersii revealed from a Duvernoy's (venom) gland transcriptome. FEBS Lett 2006;580:4417-22.

[26] Solórzano A, Cerdas L. A new subspecies of the bushmaster, Lachesis muta, from southeastern Costa Rica. J Herpetol 1986;20:463-6.

[27] Málaque CMS, Franca FOS. Acidente laquético. In: Cardoso JLC, Franca FOS, Wen FH, Málaque CMS, Hadad V, editors. Animais Peçonhentos no Brasil. Biología, Clínica e Terapéutica dos Accidentes. Sao Paulo: Sarvier; 2003. p. 87-90.

[28] Brown JH. Toxicology and Pharmacology of Venoms from Poisonous Snakes. Springfield: Illinois: Charles C. Thomas; 1973. ISBN 0-398-02808-7.

[29] Crescenti EJ, Croci M, Rivera E, Bergoc RM. Enhanced tolerance to high cytostatic doses by means of oligoelements Mn, Se, 
and $\mathrm{Zn}$ plus Lachesis muta venom: in vivo and in vitro studies. J Trace Elem Exp Med 2003;16:39-53.

[30] Crescenti EJ, Rivera E, Croci M, Cricco GM, Martin GA, Bergoc RM. Effect of oligoelements Se, $\mathrm{Zn}$ and Mn plus Lachesis muta on Panc-1 cell line growth. Int J Cancer 2002; S13:193-4

[31] Otero R, Furtado MF, Gonçalves C, Núñez V, García ME, Osorio RG, et al. Comparative study of the venoms of three subspecies of Lachesis muta (bushmaster) from Brazil, Colombia and Costa Rica. Toxicon 1998;36:2021-7.

[32] Altschul SF, Madden TL, Schaffer AA, Zhang J, Zhang Z, Miller W, et al. Gapped BLAST and PSI-BLAST: a new generation of protein database search programs. Nucleic Acids Res 1997;25:3389-402.

[33] Le Blanc JC, Hager JW, Ilisiu AM, Hunter C, Zhong F, Chu I. Unique scanning capabilities of a new hybrid linear ion trap mass spectrometer (Q TRAP) used for high sensitivity proteomics applications. Proteomics 2003;3:859-69.

[34] Wetton JH, Carter RE, Parkin DT, Walters D. Demographic study of a wild house sparrow population by DNA fingerprinting. Nature 1987;327:147-9.

[35] Soares MR, Oliveira-Carvalho AL, Wermelinger LS, Zingali RB, Ho PL, Junqueira-de-Azevedo ILM, et al. Identification of novel bradykinin-potentiating peptides and C-type natriuretic peptide from Lachesis muta venom. Toxicon 2005;46:31-8.

[36] Joseph R, Pahari S, Hodgson WC, Kini R. Hypotensive agents from snake venoms. Curr Drug Targets Cardiovasc Haematol Disord 2004:4:437-59.

[37] Fernandez JH, Neshich G, Camargo ACM. Using bradykinin-potentiating peptide structures to develop new antihypertensive drugs. Genet Mol Res 2004;3:554-63.

[38] Zamudio KR, Greene HW. Phylogeography of the bushmaster (Lachesis muta: Viperidae): implications for neotropical biogeography, systematics and conservation. Biol J Linn Soc 1997;62:421-42.

[39] Sanchez EO, Magalhães A. Purification and partial characterization of an L-amino acid oxidase from bushmaster snake (Sururucu Pico de Jara) Lachesis muta muta venom. Braz J Biol Res 1991;24:249-60.

[40] Scarborough RM, Rose JW, Naughton MA, Phillips DR, Nannizzi L, Arfsten A, et al. Characterization of the integrin specificities of disintegrins isolated from American pit viper venoms. J Biol Chem 1993;268:1058-65.

[41] Menezes MC, Furtado MF, Travaglia-Cardoso SR, Camargo AC, Serrano SM. Sex-based individual variation of snake venom proteome among eighteen Bothrops jararaca siblings. Toxicon 2005;47:304-12.

[42] Tsai IH, Wang YM, Chen YH, Tu AT. Geographic variations, cloning, and functional analyses of the venom acidic phospholipases A2 of Crotalus viridis viridis. Arch Biochem Biophys 2003;411:289-96.

[43] Mackessy SP. Venom ontogeny in the Pacific rattlesnakes Crotalus viridis helleri and C. $v$. oreganus. Copeia 1988;1988:92-101.

[44] Jurado JD, Rael EL, Lieb CS, Nakayasu E, Hayes WK, Bush SP, et al. Complement inactivating proteins and intraspecies venom variation in Crotalus oreganus helleri. Toxicon 2007;49:339-50.

[45] Guércio RAP, Shevchenko A, Shevchenko A, López-Lozano JL, Paba J, Sousa MV, et al. Ontogenetic variations in the venom proteome of the Amazonian snake Bothrops atrox. Proteome Sci 2006;4:11.

[46] Saldarriaga MM, Otero R, Núñez V, Toro MF, Díaz A, Gutiérrez JM. Ontogenetic variability of Bothrops atrox and
Bothrops asper snake venoms from Colombia. Toxicon 2003;42:405-11.

[47] Fully AL, de Miranda ALP, Zingali RB, Guimarães JA. Purification and characterization of a phospholipase $\mathrm{A}_{2}$ isoenzyme isolated from Lachesis muta snake venom. Biochem Pharmacol 2002;63:1589-97.

[48] Damico DCS, Lilla S, de Nucci G, Ponte-Soto LA, Winck FV, Novello JC, et al. Biochemical and enzymatic characterization of two basic Asp49 phospholipase $A_{2}$ isoforms from Lachesis muta muta (Surucucu) venom. Biochem Biophys Acta 2005;1726:75-86

[49] Damico DCS, Bueno LGF, Rodrigues-Simioni L, Marangoni S, Cruz-Höfling MA, Novello JC. Functional characterization of a basic D49 phospholipase $A_{2}$ (LmTX-I) from the venom of Lachesis muta muta (bushmaster). Toxicon 2006;47:759-65.

[50] Ohno M, Chijiwa T, Oda-Ueda N, Ogawa T, Hattori S. Molecular evolution of myotoxic phospholipases $\mathrm{A}_{2}$ from snake venom. Toxicon 2003;42:841-54.

[51] Kordis D, Bdolah A, Gubensek F. Positive Darwinian selection in Vipera palaestinae phospholipase $\mathrm{A}_{2}$ genes is unexpectedly limited to the third exon. Biochem Biophys Res Commun 1998;251:613-9.

[52] Valiente C, Moreno E, Sittenfeld A, Lomonte B, Gutiérrez JM. An electrophoretic study on phospholipase $A_{2}$ isoenzymes in the venoms of Central American crotaline snakes. Toxicon 1992;30:815-23.

[53] Chijiwa T, Yamaguchi Y, Ogawa T, Deshimaru M, Nobuhisa I, Nakashima $\mathrm{K}$, et al. Interisland evolution of Trimeresurus flavoviridis venom phospholipase $\mathrm{A}_{2}$ isozymes. J Mol Evol 2003;56:286-93.

[54] Creer S, Malhotra A, Thorpe RS, Stöcklin RS, Favreau PS, Hao CWS. Genetic and ecological correlates of intraspecific variation in pitviper venom composition detected using matrix-assisted laser-desorption time-of-flight mass spectrometry (MALDI-TOF-MS) and isoelectric focusing. J Mol Evol 2003;56:317-29.

[55] Linch VJ. Inventing an arsenal: adaptive evolution and neofunctionalization of snake venom phospholipase $\mathrm{A}_{2}$ genes. BMC Evol Biol 2007;7:2.

[56] Chuman Y, Nobuhisa I, Ogawa T, Deshimaru M, Chijiwa T, Tan NH, et al. Regional and accelerated molecular evolution in group I snake venom gland phospholipase $\mathrm{A}_{2}$ isozymes. Toxicon 2000;38:449-62.

[57] Silva-Haad J. Accidentes humanos por las serpientes de los géneros Bothrops y Lachesis. Mem Inst Butantan 1980/81;44/ 45:403-23.

[58] Bolaños R, Rojas O, Ulloa CE. Aspectos biomédicos de cuatro casos de mordedura de serpiente por Lachesis muta (Ophidia: Viperidae) en Costa Rica. Rev Biol Trop 1982;30:53-8.

[59] Otero R, Tobón GS, Gómez LF, Osorio RG, Valderrama R. Bites from the bushmaster (Lachesis muta) in Antioquia and Chocó, Colombia. Report of five accidents. Toxicon 1993;31:158-9.

[60] Jorge MT, Sano-Martins IS, Tomy SC, Castro SCB, Ferrrari RA, Ribeiro LA, et al. Snakebite by the bushmaster (Lachesis muta) in Brazil: case report and review of the literature. Toxicon 1997;35:545-54.

[61] Mènez A. Functional architectures of animal toxins: a clue to drug design? Toxicon 1998;36:1557-72.

[62] Harvey AL, Bradley KN, Cochran SA, Rowan EG, Pratt JA, Quillfeldt JA, et al. What can toxins tell us for drug discovery? Toxicon 1998;36:1635-40.

[63] Koh DCI, Armugam A, Jeyaseelan K. Snake venom components and their applications in biomedicine. Cell Mol Life Sci 2006;63:3030-41. 